\title{
Beneficial Use of Water Treatment Sludge in Geotechnical Applications as a Sustainable Alternative to Preserve Natural Soils
}

\author{
Maria E. G. Boscov*(D), Juliana K. Tsugawa and Edy L. T. Montalvan \\ Structural and Engineering Department, School of Engineering, University of Sao Paulo, \\ Sao Paulo 05508-970, Brazil; jukeiko@usp.br (J.K.T.); edytemon@gmail.com (E.L.T.M.) \\ * Correspondence: meboscov@usp.br; Tel.: +55-119-913-79203
}

check for updates

Citation: Boscov, M.E.G.; Tsugawa, J.K.; Montalvan, E.L.T. Beneficial Use of Water Treatment Sludge in Geotechnical Applications as a Sustainable Alternative to Preserve Natural Soils. Sustainability 2021, 13, 9848. https://doi.org/ $10.3390 /$ su13179848

Academic Editors: Gemmina Di Emidio, Ecem Nur Barisoglu and Muhammad Khizar Khan

Received: 12 July 2021

Accepted: 26 August 2021

Published: 2 September 2021

Publisher's Note: MDPI stays neutral with regard to jurisdictional claims in published maps and institutional affiliations.

Copyright: (c) 2021 by the authors. Licensee MDPI, Basel, Switzerland. This article is an open access article distributed under the terms and conditions of the Creative Commons Attribution (CC BY) license (https:// creativecommons.org/licenses/by/ $4.0 /)$.
Abstract: This paper explores the feasibility of employing drinking water treatment sludge (WTS) mixed with soils, lime, or rock powder in geotechnical applications, as well as discusses the sustainability of the approach based on experimental results, aiming at the beneficial reuse of waste and the preservation of natural geomaterials. The selected materials were two soils largely used in earthworks, two WTSs, a high purity calcium hydrated lime, and rock powder from a granitic-gneissic quarry, all occurring in São Paulo State, Brazil. The mixtures were chemically, mineralogically, and geotechnically characterized, and the geotechnical properties permeability, shear strength, and deformability were investigated. Soil-WTS mixtures showed hydraulic conductivity $\left(10^{-10}-10^{-6} \mathrm{~m} / \mathrm{s}\right.$, depending on soil and WTS), effective cohesion (10-30 kPa), friction angle $\left(34^{\circ}-40^{\circ}\right)$, undrained strength $(>50 \mathrm{kPa})$, and compression index (0.1-0.4) compatible with those of soils usually employed in earthworks. Lime:WTS and rock powder:WTS mixtures achieved $50 \mathrm{kPa}$ undrained strength for WTS contents lower than $24 \%$ and $8 \%$, respectively, and could be used as daily and intermediate covers of waste landfills, as well as in other applications with low soliciting stresses. The possibility of WTS being pumped instead of transported by trucks was analyzed in the light of results from rheological tests.

Keywords: waste utilization; waste characterization; geotechnical; mechanical and hydraulic properties; sustainability

\section{Introduction}

Water treatment sludge (WTS) is the residue generated at water treatment plants (WTPs) by the regular washing of decanters and filters. The main treatment processes to transform raw water into potable water in a conventional WTP are coagulation, flocculation, decantation, filtration, $\mathrm{pH}$ correction, disinfection, and fluoridation. During these processes, several chemicals are added to the water, e.g., chlorine, coagulants, lime, and fluorine. Coagulants (ferric, alum, polymeric) cause impurities to accumulate at the bottom of sedimentation basins and filters, which are periodically washed, producing WTS. Considering that WTS generation amounts to $0.2 \%$ to $5 \%$ of the volume of treated water [1] and the estimated increase in global demand for potable water is of $1 \%$ per year [2], WTS figures as a major waste stream, presently and for the foreseeable future.

WTS is composed of more than $97 \%$ water, chemical compounds from the treatment process, and suspended solids, mainly soil particles—sand, silt, and clay, but may also present organic matter, algae, bacteria, and viruses. Dewatering usually raises the solids content to $20-30 \%$, which corresponds to $250-400 \%$ gravimetric water content, i.e., a suspension.

In most developing countries, WTS is still released in water bodies-a practice no longer allowed in countries with sound environmental regulations-causing silting and deterioration of water quality. Environment-friendly alternatives, such as disposal in 
sanitary or dedicated landfills or discharge in sewage treatment plants (STPs), still pose sustainability concerns: WTS impairs the structural stability of sanitary landfills and overloads STPs, by themselves insufficient in most developing countries, while dedicated landfills conflict with the global environmental goal of reducing land disposal of waste. On the other hand, reuse may introduce WTS in the circular economy and also substitute natural resources in several production processes. The percentage of reused or recycled WTS is an indicator proposed by the standard ISO 24512:2007 for the evaluation of water supply services management. Sustainable management of WTS is also encompassed by UN Sustainable Development Goal 6-Water and Sanitation [3].

Some techniques aiming at WTS reuse have been investigated: precast concrete elements, brick, ceramic, and cement production [4-8]; composting [9]; removal of phosphorous from residual waters [10-12]; crop production [13] and forestry [14]; absorption of heavy metals [15,16]; coagulant recovery [17,18]; landfill lining $[19,20]$; geotechnical material [21-24], among others. Reviews about the beneficial reuse/recycling alternatives for WTS have been presented by some authors [25-27]. Despite the significant number of studies, worldwide cases of WTS reuse are rare in the literature. Novel management practices, such as agriculture, forestry, land reclamation, incorporation into soils, soil improvement, and incorporation into construction materials have been reported in the 2000s by governmental agencies in some countries (e.g., UK, Japan, France, Germany, USA), still representing low percentages of the total mass generated. However, information has not been updated in recent years on the respective websites or in regulations or technical reports. Reuse of wastewater and sewage sludge, i.e., biosolids, which are much more voluminous and with a wider range of applications, may have overshadowed the use of WTS. This does not mean that WTS reuse is not taking place; for example, WTS is used as an additive for sewage treatment in Portugal, and USEPA established directives for WTS reuse in 2011. Developing countries, however, still need sound research to enhance WTS reuse under their specific conditions and need information on the performance of practical applications already under way. Though still scarce, research on the geotechnical properties and practical applications of WTS has increased in the last years. This paper investigates the feasibility of employing WTS at as-collected water content in geotechnical applications, such as covers and bottom liners of sanitary and industrial landfills, backfill for trenches, bridge abutments and geosynthetic-reinforced earth walls, pavement and buildings subbases, reinforcement for soft soils, and embankments. Additionally, it discusses the sustainability of this approach based on experimental results, aiming at the beneficial reuse of waste and the preservation of natural geomaterials.

Two approaches are envisaged: (1) the partial substitution of soils with adequate geotechnical properties by WTS in order to preserve natural resources; (2) the mixing of WTS with additives to design a new geomaterial, aiming at beneficial reuse.

WTS addition may reduce the shear strength, increase the compressibility, or impair the workability of soils; therefore, the maximum allowable content of WTS was sought in the first approach. Two sludges and two soils were mixed in different proportions, and geotechnical properties were determined for the mixtures.

The second approach investigated WTS-additive mixtures that could reach a minimum undrained strength for workability and spreading in the field. In this case, a sludge was mixed separately with lime and rock powder to obtain a workable material for applications involving low soliciting stresses. Experimental adaptations to deal with materials with shear strength lower than that of soft clays are presented. The scientific background to integrate rheology into geotechnical tests discussed in [28] is here first applied to WTS. Subsequent steps will be to produce materials with good geotechnical properties for general earthworks.

The experimental results of both approaches are finally discussed in the light of technical feasibility, as well as environmental, economic, and social sustainability. The discussion perspective focuses on developing countries, where environmental regulations and new business models for water and sanitation are still being implemented. 
The new approaches and the scientific contribution of this research are (1) the geotechnical utilization of as-collected WTS, without any previous treatment such as drying or chemical addition, which would drastically reduce the economic feasibility of reuse (air or oven-drying improves the geotechnical properties of WTS, but is time, space, and energy consuming); (2) the determination of geotechnical properties for multipurpose applications - while most investigations are directed toward a specific use and therefore may discard suitable materials for geotechnical applications other than those previously envisioned, the multipurpose approach can itself indicate the best alternative of reuse; and (3) the integration of geotechnical and rheological tests to understand the behavior of geomaterials and to discuss new possibilities of transport and manipulation in the light of sustainability.

\section{Materials and Methods}

\subsection{Materials}

Two WTSs were investigated, Cubatão-WTS and Taiaçupeba-WTS, both generated at conventional-treatment WTPs located in São Paulo State, Brazil (Figure 1). Samples of both WTSs were collected directly after centrifuge dewatering. The protocol to obtain representative samples was designed according to the Theory of Sampling [29].
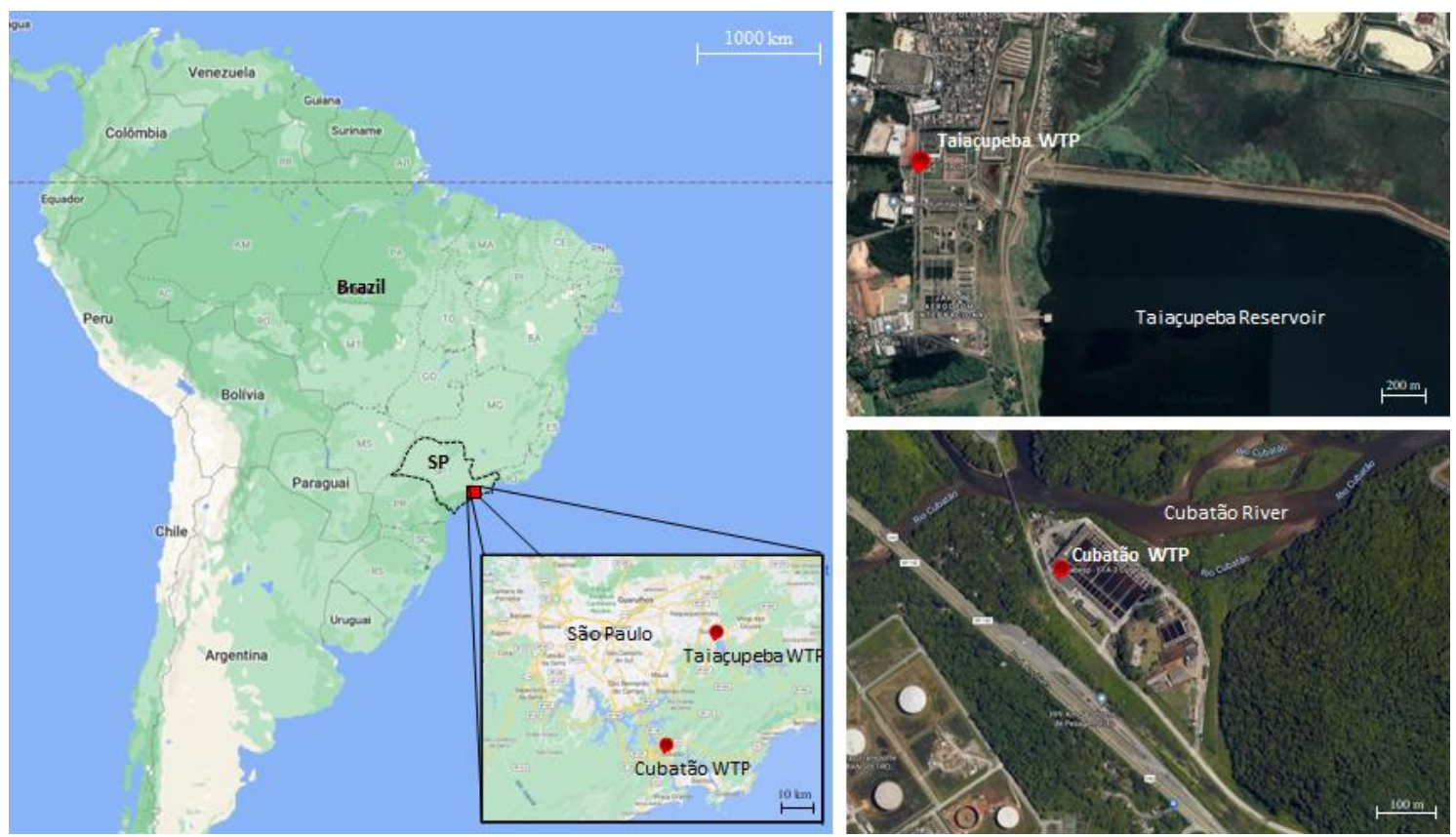

Figure 1. Location of Cubatão-WTP, Cubatão River, Taiaçupeba-WTP and Taiaçupeba Reservoir.

Cubatão-WTP collects raw water with turbidity of 800 NTU from the Cubatão River and supplies $4.5 \mathrm{~m}^{3} / \mathrm{s}$ of potable water to a 1.5 million population. The water passes through desanders before being submitted to the conventional treatment, which uses ferric chloride as a coagulant. WTS produced by washing sedimentation basins and filters is sent to a thickening tank ( $2 \%$ to $4 \%$ solids) and then dewatered by centrifuges, generating circa 60 tons / day of WTS with $20 \%$ to $25 \%$ solids. Cubatão-WTS is presently sent to a private waste disposal site.

Taiaçupeba-WTP collects raw water from the Taiaçupeba reservoir and produces $15 \mathrm{~m}^{3}$ /s of potable water for the São Paulo Metropolitan Region (21 million inhabitants). The coagulation process employs aluminum sulfate and a polymer (superfloc 8392). Residues collected from the sedimentation basins and filters backwashing are sent to an equalization tank ( $2 \%$ solids content), then to a thickening tank ( $4 \%$ solids content), and 
finally to centrifuges (16\% to $18 \%$ solids content). WTS is further air-dried and disposed of in engineered cells inside the WTP or sent to an external landfill.

Two tropical lateritic soils widely used in geotechnical works were selected for the research: Botucatu clayey sand and Campinas clay, both largely occurring soils in Sao Paulo State, Brazil. Additives were a commercial high-purity calcium hydrated lime and granite-gneiss rock powder collected in a quarry in Cubatão, São Paulo State.

All mixtures were prepared with WTS at as-collected water content (after centrifugedewatering), and soils, lime, and rock powder were prepared at hygroscopic water content. Soils were air-dried, a usual practice in soil mechanics laboratories, while lime and rock powder were already obtained in a dry state. The proportions of WTS and mixed material by wet mass were selected according to an arbitrary criterion of workability/compactability of the resulting mixture. For the analysis of test results, WTS content was expressed by dry mass basis (mass of WTS solids divided by mass of soil, lime, or rock powder solids).

Three soil:WTS ratios by wet mass were selected between 1.5:1 and 5:1, resulting in 12 different mixtures. Four lime:WTS ratios by wet mass, varying between 1:1 and 1.5:1, and four rock powder:WTS ratios, between 1:1 and 5:1, were also tested. Mixtures were named with letters sequentially indicating soil or additive, WTS, and soil:WTS or additive:WTS ratio, as presented in Table 1.

Table 1. Tested mixtures: composition and notation.

\begin{tabular}{|c|c|c|c|c|}
\hline Notation. & Soil or Additive & WTS & $\begin{array}{c}\text { Proportion } \\
\text { (by Wet Mass) }\end{array}$ & $\begin{array}{c}\text { WTS Content (\%) } \\
\text { (by Dry Mass) }\end{array}$ \\
\hline BC5:1 & Botucatu sand & Cubatão & $5: 1$ & 4.5 \\
\hline BC4:1 & Botucatu sand & Cubatão & $4: 1$ & 5.6 \\
\hline BC3:1 & Botucatu sand & Cubatão & $3: 1$ & 7.5 \\
\hline BT5:1 & Botucatu sand & Taiaçupeba & $5: 1$ & 3.4 \\
\hline BT4:1 & Botucatu sand & Taiaçupeba & $4: 1$ & 4.2 \\
\hline BT3:1 & Botucatu sand & Taiaçupeba & $3: 1$ & 5.7 \\
\hline CC $4: 1$ & Campinas clay & Cubatão & $4: 1$ & 7.0 \\
\hline CC3:1 & Campinas clay & Cubatão & $3: 1$ & 9.3 \\
\hline CC2:1 & Campinas clay & Cubatão & $2: 1$ & 13.9 \\
\hline СТ3:1 & Campinas clay & Taiaçupeba & $3: 1$ & 5.7 \\
\hline $\mathrm{CT} 2: 1$ & Campinas clay & Taiaçupeba & $2: 1$ & 8.5 \\
\hline CT1.5:5 & Campinas clay & Taiaçupeba & $1.5: 1$ & 11.3 \\
\hline LC1:1 & Lime & Cubatão & $1: 1$ & 28.6 \\
\hline LC1.2:1 & Lime & Cubatão & $1.2: 1$ & 25.0 \\
\hline LC1.3:1 & Lime & Cubatão & $1.3: 1$ & 22.2 \\
\hline LC1.5:1 & Lime & Cubatão & $1.5: 1$ & 20.0 \\
\hline RPC2.1:1 & Rock Powder & Cubatão & 2.1:1 & 14.3 \\
\hline RPC3:1 & Rock Powder & Cubatão & $3: 1$ & 10.0 \\
\hline RPC4:1 & Rock Powder & Cubatão & $4: 1$ & 7.4 \\
\hline RPC5:1 & Rock Powder & Cubatão & $5: 1$ & 5.9 \\
\hline
\end{tabular}

\subsection{Chemical and Mineralogical Characterization of the Investigated Materials}

Chemical composition was obtained by X-ray fluorescence using a spectrometer (Axios-Advanced PANalytical; standardless analysis from fluor to uranium) and loss-onignition (LOI) at $1020^{\circ} \mathrm{C}$ for two hours. Analyses were carried out on powder of oven-dried samples $\left(35^{\circ} \mathrm{C}\right)$. Concentrations of elements were semiquantitative and presented in the form of oxides normalized to the value of $100 \%$. Chemical parameters, $\mathrm{pH}$ in water and $\mathrm{KCl}, \mathrm{P}, \mathrm{K}, \mathrm{Ca}, \mathrm{Mg}, \mathrm{Al}, \mathrm{Al}+\mathrm{H}$, exchangeable bases, cation exchange capacity, saturation by exchangeable bases, saturation by aluminum, organic carbon, and organic matter by titrimetric method were determined using air-dried samples according to methods of the Brazilian Agricultural Research Corporation [30]. In order to determine organic matter content, $100 \mathrm{~g}$ samples were oven dried at $105^{\circ} \mathrm{C}$ and then ignited using a muffle furnace at $440{ }^{\circ} \mathrm{C}$ during $24 \mathrm{~h}$, in accordance with ASTM D2974 standard. 
Mineral composition was determined by X-ray diffraction using Phillips diffractometer MPD 1880 and scanning electron microscopy (SEM) using FEI Quanta m600 FEG microscope, equipped with a Bruker X-ray energy dispersion spectrometer (EDS) Quantax 400 (technology SDD-Silicon Drift Detector) and data analysis using Sprit software. The analyses were conducted on samples oven-dried at $35^{\circ} \mathrm{C}$. Crystalline phases were identified by comparing obtained diffractograms with those of the International Centre of Diffraction Data and the PANalytical Inorganic Crystal Structure Database. Microscopic analyses were carried out by collection of backscattered electron images and specific chemical analyses by EDS for the compositional characterization of particles. The SEM analyses were conducted on pulverized samples (powder) glued to a double-sided carbon tape and coated with platinum.

\subsection{Geotechnical Characterization of the Materials}

Geotechnical characterization comprised determination of water content $(\mathrm{w})$, particlesize distribution (PSD), liquid limit $\left(\mathrm{w}_{\mathrm{L}}\right)$ and plastic limit $\left(\mathrm{w}_{\mathrm{P}}\right)$, specific gravity of solids (Gs), and organic matter content (OM), following ASTM standards: ASTM-D2974-14, ASTM-D422-07, ASTM-D4318-17, ASTM-D854-14, and ASTM-D2974-14, respectively.

For the sludges, solids content (SC) and dehydration over time were also determined: $2 \mathrm{~kg}$ samples were air-dried and monitored over time until reaching the residual water content. Water content was determined at $105^{\circ} \mathrm{C}$ following the recommendation of [31] for organic sludges. For the other characterization tests, WTS samples were tested at as-collected water content since several authors have reported significant alterations in WTS caused by previous air-drying [32-35]. Atterberg limits were determined by the wet method (from wet to dry) following ASTM D4318-17. PSD of the sludges was also determined by laser analyses using wet and dry (powder) samples.

\subsection{Geotechnical Properties of the Investigated Materials}

Compaction tests at standard Proctor effort followed ASTM-D698-12e2 with air-dried samples (Method A) and material reuse (necessary due to the great number of compaction tests since each test uses $\sim 3 \mathrm{~kg}$ of material). Compaction of additive:WTS mixtures was carried out after previous drying to hygroscopic moisture. Compaction of soil:WTS mixtures was carried out with and without previous drying. Refs. $[35,36]$ showed that previous air-drying alters compaction parameters (maximum dry unit weight and optimum water content) of soil:WTS mixtures and that there is a linear correlation between compaction parameters and desiccation ratio, defined according to Equation (1). Compaction tests for each soil:WTS mixture were conducted at three different desiccation ratios.

$$
\text { Desiccation ratio }(\%)=\frac{\mathrm{w}_{0}-\mathrm{w}_{\mathrm{i}}}{\mathrm{w}_{0}} \times 100
$$

where $\mathrm{w}_{0}=$ as-mixed water content, and $\mathrm{w}_{\mathrm{i}}=$ water content after air-drying.

Soils and soil:WTS mixtures specimens were submitted to oedometric compression, permeability, unconfined compression, and triaxial compression tests. Specimens were compacted at optimum compaction parameters at Proctor standard effort. However, some mixtures (those with higher WTS content) were tested at as-mixed moisture, as they already were slightly wet-of-optimum. Additive:WTS mixtures were submitted to unconfined compression tests on specimens compacted at as-mixed water content at Proctor standard effort. When the stress-strain curve did not present a peak, i.e., the axial stress continuously increased with strain, the adopted failure criterion was 15\% (maximum) deformation.

Oedometric compression tests were carried out according to ASTM- D2435-11a, with the specimen inside a stainless-steel ring of $71.3 \mathrm{~mm}$ diameter and $20.0 \mathrm{~mm}$ height, inundation with distilled water at initial loading, incremental loading (load increment ratio of 1), subsequent unloading, and loading interval of $24 \mathrm{~h}$. The applied vertical stresses were: 10, $20,40,80,160,320,640,1280$, and $2560 \mathrm{kPa}$. 
The hydraulic conductivity of compacted soils and soil:WTS mixtures was determined by constant head permeability tests in flexible-wall permeameter, following ASTM-D508416, with specimens of $70 \mathrm{~mm}$ height and $70 \mathrm{~mm}$ diameter. Saturation was achieved by backpressure ranging from 500 to $700 \mathrm{kPa}$ to reach B-value equal or higher than 0.96 .

For each soil and soil:WTS mixture, isotropically consolidated undrained (CIU) triaxial compression tests with measurement of pore pressure were carried out with confining pressures of 50,100 , and $200 \mathrm{kPa}$ on specimens of $38 \mathrm{~mm}$ diameter and $76 \mathrm{~mm}$ height, following ASTM-D4767-11. The undrained strength was defined as the maximum deviator stress till axial strain of $17 \%$.

Unconfined compression tests were carried out following ASDTM-D2166-16 at $1.0 \%$ min strain rate with triplicate specimens of $50 \mathrm{~mm}$ diameter and $50 \mathrm{~mm}$ height (compacted by mini-MCV equipment) for each material. Since the L/D ratio of the specimens was 1 , a correction factor of 0.69 was applied to the maximum axial stress in order to obtain the equivalent axial stress for $\mathrm{L} / \mathrm{D}=2$, based on the correction equation suggested by [37].

$$
\operatorname{UCS}_{\left(\frac{\mathrm{L}}{\mathrm{D}}=2\right)}=\frac{\operatorname{UCS}_{\left(\frac{\mathrm{L}}{\mathrm{D}}\right)}}{\left[1.83-0.39\left(\frac{\mathrm{L}}{\mathrm{D}}\right)\right]}
$$

where $\mathrm{UCS}_{(\mathrm{L} / \mathrm{D}=2)}=$ standard unconfined compression strength, and $\mathrm{UCS}_{(\mathrm{L} / \mathrm{D})}=$ measured UCS for tested samples with L/D ratio.

\subsection{Environmental Characterization of Cubatão-WTS and Taiaçupeba-WTS}

The environmental characterization of Cubatão-WTS was based on the chemical analysis of four different samples submitted to X-ray fluorescence in two laboratories. The Brazilian standard for waste classification NBR 10,004 [38] uses specific properties (radioactivity, inflammability, pathogenicity, and corrosivity) or results of solubilization and leaching tests to classify waste in three classes-hazardous, non-hazardous non-inert, and non-hazardous inert. NBR 10,004 implicitly considers WTS, municipal solid waste, and sewage treatment sludge as non-hazardous non-inert. Even so, since the quality of the raw water of Taiaçupeba Reservoir posed some concern, solubilization and leaching tests were carried out for Taiaçupeba-WTS following Brazilian standards NBR 10,006 [39] and NBR 10,005 [40], respectively. Ongoing research aims to analyze the chemical impact of WTS reuse at each specific geotechnical application.

Biological characterization of WTS is not required yet, despite the probable presence of microorganisms, hormones, and nano plastics that are not destroyed by the conventional treatment. Further research is necessary to address this topic.

\subsection{Rheological Behavior of Cubatão-WTS}

A sample of Cubatão-WTS at water content of $240 \%$ (solids content of $30 \%$ ) was mechanically mixed for $1 \mathrm{~min}$ at $10,000 \mathrm{rpm}$ before the rotational rheometry tests. Stepped flow tests were performed using a Haake Mars 60 Rheometer with steel parallel plate geometry (diameter of $35 \mathrm{~mm}$, gap of $1.0 \mathrm{~mm}$ ) at a constant temperature of $23^{\circ} \mathrm{C}$. Shear strain rate (usually named "shear rate" at rotational tests) was twice increased (acceleration) from 0 to $50 \mathrm{~s}^{-1}$ (3000 rpm) and subsequently decreased (deceleration)-i.e., two cycles of shear rate acceleration-deceleration were performed, totalizing $400 \mathrm{~s}$ of test (Figure 2). 


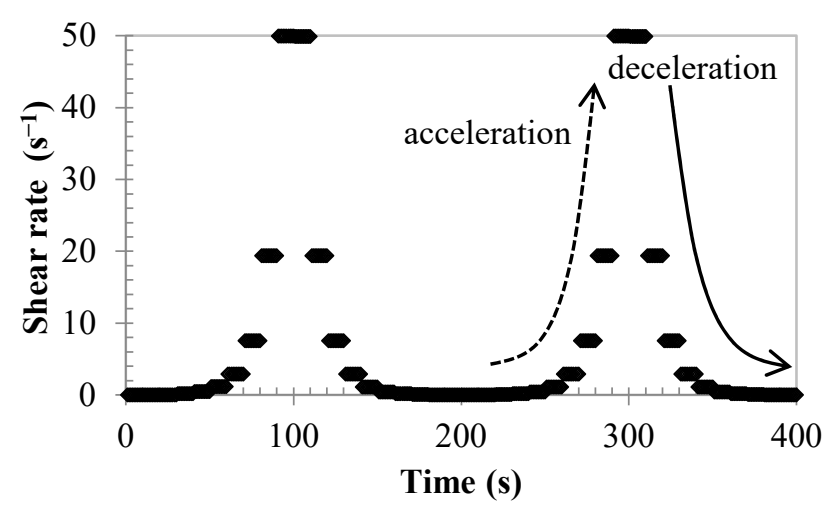

Figure 2. Shear rate history applied during "stepped flow" or "stepwise flow" rheology tests [41].

\subsection{Particular Aspects of WTS Characterization}

Characterization of WTS is challenging because quantities and characteristics vary not only among different WTPs but also within the same WTP along any given year. Great variations in WTS composition (organic matter, clay, and sand particles) due to seasonality of raw water quality have been reported [6]. The sampling procedure of both sludges was based on the Theory of Sampling to warrant a homogeneous sample representative of one month of WTS generation [42].

WTS characterization has been discussed in a recent technical event in Brazil, LETA 2021 (First Meeting on Water Treatment Sludge: Connections for Technology Innovation), which brought together professionals and researchers dealing with WTS to disclose the state-of-the-art in this subject and to propose new lines of action. Our position, which was in accordance with that of many colleagues who deal with WTS, is that WTS should be characterized according to the desired application. For instance, grain size distribution is fundamental for use in the ceramics industry since different ceramic elements demand suitable ranges of clay and sand fractions. On the other hand, mineralogical characterization is necessary for the cement industry since predominance of amorphous material disqualifies WTS for this application. Mineralogical classification is also important to identify active clay minerals for coagulant, phosphorous, or heavy metals recuperation. Micro and macro properties of WTS are intrinsically related [43] and should be selected for characterization according to each potential use.

Environmental characterization, on the other hand, should be related to WTS conditioning when reused. A WTS that presents heavy metals might release excessive concentrations if used in a compacted soil layer exposed to weather; however, leaching of these metals might not occur if the WTS is encapsulated in a concrete-bitumen matrix.

\section{Results}

\subsection{Characterization of Cubatão-WTS and Taiaçupeba-WTS}

\subsubsection{Chemical and Mineralogical}

The chemical composition of both WTSs obtained by X-ray fluorescence in terms of major elements is presented in Table 2, while chemical parameters are presented in Table 3. The mineralogical tests show that Cubatão-WTS is composed of quartz, goethite, muscovite, and kaolinite, mineralogically compatible with the gneissic rocks and residual soils through which the Cubatão River flows. Taiaçupeba-WTS, collected in a reservoir, is mainly composed of amorphous phase, with traces of quartz, gibbsite, and kaolinite. There are three main likely sources of amorphous material in Taiaçupeba-WTS: organic matter, expected because raw water comes from a reservoir; amorphous aluminum or iron (hydr)oxides from the coagulant; and the polymer of high molecular weight that Taiaçupeba-WTP uses for coagulation and dewatering improvement. 
Table 2. Chemical composition of Cubatão-WTS and Taiaçupeba-WTS (percentage by dry mass).

\begin{tabular}{ccc}
\hline Oxide & Cubatão-WTS & Taiaçupeba-WTS \\
\hline $\mathrm{SiO}_{2}$ & 18.3 & 4.87 \\
$\mathrm{Al}_{2} \mathrm{O}_{3}$ & 8.89 & 29.6 \\
$\mathrm{Fe}_{2} \mathrm{O}_{3}$ & 46.0 & 12.3 \\
$\mathrm{MnO}$ & 0.21 & 0.32 \\
$\mathrm{MgO}$ & 0.438 & $<0.10$ \\
$\mathrm{CaO}$ & 1.59 & 0.49 \\
$\mathrm{Na}_{2} \mathrm{O}$ & 0.10 & $<0.10$ \\
$\mathrm{~K}_{2} \mathrm{O}$ & 1.00 & $<0.10$ \\
$\mathrm{TiO}_{2}$ & 0.417 & 0.17 \\
$\mathrm{P}_{2} \mathrm{O}_{5}$ & 0.249 & 0.45 \\
LOI (Loss-on-Ignition) & 22.0 & 52.6 \\
\hline
\end{tabular}

Table 3. Chemical parameters of Cubatão-WTS and Taiaçupeba-WTS.

\begin{tabular}{|c|c|c|}
\hline Parameter & Cubatão-WTS & Taiaçupeba-WTS \\
\hline $\mathrm{pH}\left(\right.$ in $\left.\mathrm{H}_{2} \mathrm{O}\right)$ & 7.0 & 6.4 \\
\hline $\mathrm{pH}\left(\mathrm{KCl} 1 \mathrm{~mol} \cdot \mathrm{L}^{-1}\right.$ solution $)$ & 5.9 & 5.6 \\
\hline$\Delta \mathrm{pH}$ & -1.1 & -0.8 \\
\hline $\mathrm{P}\left(\mathrm{mg} \cdot \mathrm{kg}^{-1}\right)$ & $<2$ & 4.2 \\
\hline $\mathrm{K}^{2+}\left(\mathrm{mmolc} \cdot \mathrm{kg}^{-1}\right)$ & 1.5 & 2.5 \\
\hline $\mathrm{Ca}^{2+}\left(\mathrm{mmolc} \cdot \mathrm{kg}^{-1}\right)$ & 266 & 32 \\
\hline $\mathrm{Mg}^{2+}\left(\mathrm{mmolc} \cdot \mathrm{kg}^{-1}\right)$ & 45 & 4 \\
\hline $\mathrm{Na}^{+}\left(\right.$mmolc $\left.\cdot \mathrm{kg}^{-1}\right)$ & 4 & 14.8 \\
\hline $\mathrm{Al}^{3+}\left(\mathrm{mmolc} \cdot \mathrm{kg}^{-1}\right)$ & 1 & 1 \\
\hline $\mathrm{H}^{+}+\mathrm{Al}^{3+}\left(\mathrm{mmolc} \cdot \mathrm{kg}^{-1}\right)$ & 9 & 20 \\
\hline $\begin{array}{l}\text { Exchangeable bases } \\
\left(\text { mmolc } \cdot \mathrm{kg}^{-1}\right)\end{array}$ & 316.5 & 53.3 \\
\hline CEC $\left(\right.$ mmolc $\left.\cdot \mathrm{kg}^{-1}\right)$ & 325.5 & 73.3 \\
\hline Base saturation (\%) & 97 & 73 \\
\hline Aluminum saturation (\%) & 0 & 2 \\
\hline Organic matter $(\%)$ & 2.4 & 26.7 \\
\hline Organic carbon $(\%)$ & 1.4 & 15.5 \\
\hline
\end{tabular}

$\overline{\mathrm{CEC}}=$ cation exchange capacity.

The chemical composition of both WTSs agrees with the corresponding mineralogical composition, coagulant, and organic matter content. For instance, high concentration of iron in Cubatão-WTS and high concentration of aluminum in Taiaçupeba-WTS are related to the use of ferric chloride and aluminum sulfate as coagulants, respectively.

For Brazilian WTSs, $\mathrm{pH}$ values have been reported to vary from 5.9 to 8.3 [44]. Both Cubatão-WTS and Taiaçupeba-WTS presented a $\mathrm{pH}$ of around 7 (Table 3). The organic matter content of Cubatão-WTS is lower than that of Taiaçupeba-WTS, as expected due to the differing water sources (river and reservoir, respectively); however, the cation exchange capacity (CEC) is higher for Cubatão-WTS than for Taiaçupeba-WTS. The mineralogical composition of Cubatão-WTS does not explain this high CEC value; it is likely that the method used for determining CEC, based on exchangeable bases, may have computed the calcium cations present due to lime addition as adsorbed cations.

\subsubsection{Geotechnical}

The geotechnical characterization of both WTSs is presented in Table 4 . Both sludges are fine materials with high liquid limits at natural moisture; however, they are located below the A-line of Casagrande's plasticity chart, i.e., their fines are not active. Both WTSs undergo irreversible cementation when subjected to air or oven-drying, Taiaçupeba-WTS more markedly than Cubatão-WTS, to the point of being classified as an organic soil. The specific gravity (Gs) values are related to the chemical composition: Gs of Cubatão-WTS is higher than that of most soils due to the high content of iron (except for lateritic soils 
which are also iron-rich), and Gs of Taiaçupeba-WTS is lower than that of most minerals due to the high organic matter content.

Table 4. Geotechnical characterization of Cubatão-WTS and Taiaçupeba-WTS.

\begin{tabular}{ccc}
\hline Parameter & Cubatão-WTS & Taiaçupeba-WTS \\
\hline Liquid limit, $\mathrm{w}_{\mathrm{L}}(\%)$ & 237 & 536 \\
Plastic index, PI $(\%)$ & 138 & 30 \\
Specific gravity of grains, $\mathrm{G}_{\mathrm{S}}$ & 2.95 & 2.42 \\
Clay fraction $(\%<2 \mu \mathrm{m})$ & 78.1 & 52.5 \\
Fines fraction $(\%<75 \mu \mathrm{m})$ & 98.3 & 95.0 \\
Sand fraction $(\%)$ & 1.7 & 5.0 \\
Organic matter, OM $(\%)$ & 19.2 & 49.0 \\
USCS ${ }^{1}$ classification & MH & OH \\
\hline
\end{tabular}

${ }^{1}$ USCS = Unified System of Soil Classification.

\subsubsection{Environmental}

Cubatão-WTS elemental concentrations by dry mass obtained for four samples at two different laboratories are displayed in Table 5 and compared with intervention values for agricultural, residential, and industrial uses according to the environmental legislation of São Paulo State [45]. The tests scanned a wide range of elements, but just those detected are shown in Table 5.

Table 5. Chemical composition of Cubatão-WTS compared with allowable values from legislation of São Paulo State [46].

\begin{tabular}{|c|c|c|c|c|c|}
\hline \multirow{2}{*}{ Element } & \multirow{2}{*}{ Average (\%) } & \multirow{2}{*}{ Coefficient of Variation (\%) } & \multicolumn{3}{|c|}{ Intervention Value $\left(\mathrm{mg} \times \mathrm{kg}^{-1}\right)$} \\
\hline & & & Agriculture & Residential & Industrial \\
\hline $\mathrm{Fe}$ & 45.2 & 21 & & & \\
\hline $\mathrm{Si}$ & 6.18 & 30 & & & \\
\hline $\mathrm{Al}$ & 3.37 & 34 & & & \\
\hline $\mathrm{Ca}$ & 1.57 & 32 & & & \\
\hline $\mathrm{K}$ & 0.66 & 31 & & & \\
\hline $\mathrm{Mg}$ & 0.25 & 23 & & & \\
\hline $\mathrm{Ti}$ & 0.22 & 19 & & & \\
\hline $\mathrm{Cl}$ & 0.14 & 15 & & & \\
\hline $\mathrm{Na}$ & 0.07 & 31 & & & \\
\hline Element & Average $\left(\mathrm{mg} \times \mathrm{kg}^{-1}\right)$ & Coefficient of variation $(\%)$ & & & \\
\hline $\mathrm{Mn}$ & 2092 & 37 & & & \\
\hline $\mathrm{P}$ & 1265 & 20 & & & \\
\hline S & 1166 & 15 & & & \\
\hline $\mathrm{Ni}$ & 525 & 111 & 190 & 480 & 3800 \\
\hline $\mathrm{Cu}$ & 414 & 85 & 760 & 2100 & 10,000 \\
\hline $\mathrm{Cr}$ & 243 & 49 & 150 & 300 & 400 \\
\hline $\mathrm{Sr}$ & 227 & 24 & & & \\
\hline $\mathrm{Zn}$ & 163 & 37 & 1900 & 7000 & 10,000 \\
\hline $\mathrm{Zr}$ & 62 & 60 & & & \\
\hline $\mathrm{Pb}$ & $<Q L$ & - & 150 & 240 & 4400 \\
\hline $\mathrm{V}$ & $<\hat{Q L}$ & - & & & \\
\hline
\end{tabular}

Concentrations of the potentially toxic elements $\mathrm{Cu}, \mathrm{Cr}$, and $\mathrm{Ni}$ show a great variability. The slightly acidic $\mathrm{pH}$ value may favor the mobility of these elements. However, total concentrations in WTS do not represent concentration in leachates. Moreover, except for $\mathrm{Ni}$, concentrations of all controlled elements are below the intervention values for the three uses.

Concentrations obtained by solubilization and leaching tests with Taiaçupeba-WTS are shown in Tables 6 and 7, compared with allowable values according to Brazilian standards [38]. 
Table 6. Concentrations obtained by leaching test compared with allowable limits according to Brazilian standards [47].

\begin{tabular}{cccc}
\hline Constituent & Measured $(\mathbf{m g} / \mathbf{L})$ & Quantification Limit $(\mathbf{m g} / \mathbf{L})$ & Maximum Allowable $(\mathbf{m g} / \mathbf{L})$ \\
\hline $\mathrm{Ag}$ & Undetected & 0.025 & 5.0 \\
$\mathrm{As}$ & Undetected & 0.025 & 1.0 \\
$\mathrm{Ba}$ & Undetected & 0.010 & 70.0 \\
$\mathrm{Cd}$ & Undetected & 0.003 & 0.5 \\
$\mathrm{Cr}$ & Undetected & 0.010 & 5.0 \\
$\mathrm{~Pb}$ & Undetected & 0.010 & 1.0 \\
$\mathrm{Se}$ & Undetected & 0.025 & 1.0 \\
$\mathrm{Hg}$ & 0.55 & 0.0008 & 0.1 \\
$\mathrm{~F}$ & 5.3 & 0.600 & 150.0 \\
$\mathrm{pH}$ & & & \\
\hline
\end{tabular}

Table 7. Concentrations obtained by solubilization test compared with allowable values according to Brazilian standards [47].

\begin{tabular}{|c|c|c|c|}
\hline Constituent & Measured (mg/L) & Quantification Limit (mg/L) & Maximum Allowable (mg/L) \\
\hline $\mathrm{Ag}$ & Undetected & 0.025 & 0.05 \\
\hline $\mathrm{Al}$ & 0.025 & 0.010 & 0.20 \\
\hline As & Undetected & 0.008 & 0.01 \\
\hline $\mathrm{Ba}$ & 0.247 & 0.010 & 0.70 \\
\hline $\mathrm{Cd}$ & Undetected & 0.003 & 0.005 \\
\hline $\mathrm{Cr}$ & Undetected & 0.010 & 0.05 \\
\hline $\mathrm{Cu}$ & Undetected & 0.010 & 2.00 \\
\hline $\mathrm{Fe}$ & 0.012 & 0.010 & 0.3 \\
\hline Mn & 3.948 & 0.005 & 0.10 \\
\hline $\mathrm{Pb}$ & Undetected & 0.007 & 0.01 \\
\hline Se & Undetected & 0.008 & 0.01 \\
\hline $\mathrm{Zn}$ & 0.008 & 0.003 & 5.0 \\
\hline $\mathrm{Hg}$ & Undetected & 0.0008 & 0.001 \\
\hline $\mathrm{Na}$ & 39.445 & 0.060 & 200.00 \\
\hline $\mathrm{SO}_{4}^{2-}$ & 75.117 & 4.0 & 250.00 \\
\hline $\mathrm{N}$ & 6.73 & 1.5 & 10.00 \\
\hline $\mathrm{Cl}^{-}$ & 193.312 & 0.5 & 250.00 \\
\hline $\mathrm{F}^{-}$ & Undetected & 0.6 & 1.50 \\
\hline $\mathrm{CN}^{-}$ & Undetected & 0.05 & 0.07 \\
\hline Phenols & 0.0189 & 0.005 & 0.01 \\
\hline $\mathrm{pH}$ & 6.99 & & \\
\hline
\end{tabular}

Leached concentrations of the analyzed constituents are lower than the allowable limits, whereas solubilized concentrations of $\mathrm{Mn}$ and phenols exceed limit values, characterizing Taiaçupeba-WTS as non-hazardous non-inert. Mn concentration may be related to chemical waste discarded in one of the rivers feeding the reservoir, while phenols may derive from chemical and industrial waste discharge as well as from decomposition of vegetation [47].

Non-hazardous non-inert waste can be co-disposed of at sanitary landfills with municipal solid waste according to Brazilian standards. Therefore, the application in sanitary landfills as daily cover is allowed; however, WTS at as-collected water content is a suspension difficult to spread in the field and impairs the stability of the waste mass. Mixture with soils and additives significantly improves the geotechnical behavior and opens a range of possibilities for reuse. For the most promising soil:WTS and additive:WTS mixtures, further environmental investigation will be carried out simulating field conditions.

\subsection{Characterization of Soils and Soil:WTS Mixtures}

\subsubsection{Chemical and Mineralogical}

The chemical composition of both soils obtained by $\mathrm{X}$-ray fluorescence is presented in Table 8, while chemical parameters are presented in Table 9. The mineralogical analysis 
shows that Botucatu clayey sand, a lateritic residual soil derived from the alternating basalt and arenite layers of Parana Basin, is composed of quartz, kaolinite, gibbsite, hematite, and anatase. Campinas clay, a lateritic residual soil derived from diabase, presents quartz, kaolinite, gibbsite, hematite, magnetite, and ilmenite, with traces of smectite. Kaolinite is the most common clay mineral found in the clay fraction of Brazilian lateritic soils [48], while crystalline aluminum and iron (hydr)oxides such as gibbsite, hematite, and goethite are also of common occurrence in the fines fraction of lateritic soils. These oxides cover and cement clay (kaolinite) particles, forming the microaggregates that compose the peculiar microstructure of lateritic soils.

Table 8. Chemical composition of Botucatu clayey sand and Campinas clay (percentage by dry mass).

\begin{tabular}{ccc}
\hline Oxide & Botucatu Clayey Sand & Campinas Clay \\
$\mathrm{SiO}_{2}$ & 68.1 & 31.1 \\
$\mathrm{Al}_{2} \mathrm{O}_{3}$ & 16.5 & 23.9 \\
$\mathrm{Fe}_{2} \mathrm{O}_{3}$ & 7.17 & 24.4 \\
$\mathrm{MnO}$ & 0.03 & 0.141 \\
$\mathrm{MgO}$ & 0.04 & 0.17 \\
$\mathrm{CaO}$ & 0.02 & 0.09 \\
$\mathrm{Na}{ }_{2} \mathrm{O}$ & - & $<0.02$ \\
$\mathrm{~K}_{2} \mathrm{O}$ & 0.04 & 0.03 \\
$\mathrm{TiO}_{2}$ & 1.55 & 5.21 \\
$\mathrm{P}_{2} \mathrm{O}_{5}$ & 0.05 & 0.14 \\
LOI (Loss-on-Ignition) & 6.11 & 14.2 \\
\hline
\end{tabular}

Table 9. Chemical parameters of Botucatu clayey sand and Campinas clay.

\begin{tabular}{|c|c|c|}
\hline Parameter & Botucatu Clayey Sand & Campinas Clay \\
\hline $\mathrm{pH}\left(\right.$ in $\left.\mathrm{H}_{2} \mathrm{O}\right)$ & 4.7 & 5.0 \\
\hline $\mathrm{pH}\left(\mathrm{KCl} 1 \mathrm{~mol} \cdot \mathrm{L}^{-1}\right.$ solution $)$ & 4.5 & 4.4 \\
\hline$\Delta \mathrm{pH}$ & -0.2 & -0.6 \\
\hline $\mathrm{P}\left(\mathrm{mg} \cdot \mathrm{kg}^{-1}\right)$ & $<2$ & $<2$ \\
\hline $\mathrm{K}^{2+}\left(\mathrm{mmolc} \cdot \mathrm{kg}^{-1}\right)$ & $<0.5$ & 2.2 \\
\hline $\mathrm{Ca}^{+}\left(\mathrm{mmolc} \cdot \mathrm{kg}^{-1}\right)$ & 2 & 21 \\
\hline $\mathrm{Mg}^{2+}\left(\mathrm{mmolc} \cdot \mathrm{kg}^{-1}\right)$ & 0.4 & 4 \\
\hline $\mathrm{Na}^{+}\left(\mathrm{mmolc} \cdot \mathrm{kg}^{-1}\right)$ & $<0.2$ & $<0.2$ \\
\hline $\mathrm{Al}^{3+}\left(\right.$ mmolc $\left.\cdot \mathrm{kg}^{-1}\right)$ & 3 & 1 \\
\hline $\mathrm{H}^{+}+\mathrm{Al}^{3+}\left(\right.$ mmolc $\left.\cdot \mathrm{kg}^{-1}\right)$ & 25 & 49 \\
\hline $\begin{array}{l}\text { Exchangeable bases } \\
\quad\left(\mathrm{mmolc} \cdot \mathrm{kg}^{-1}\right)\end{array}$ & 2.2 & 27.3 \\
\hline CEC (mmolc $\left.\cdot \mathrm{kg}^{-1}\right)$ & 27.2 & 76.3 \\
\hline Base saturation $(\%)$ & 8 & 36 \\
\hline Aluminum saturation (\%) & 58 & 4 \\
\hline Organic matter $(\%)$ & 0.9 & 2.5 \\
\hline Organic carbon $(\%)$ & 0.5 & 1.4 \\
\hline
\end{tabular}

$\overline{\mathrm{CEC}}=$ cation exchange capacity.

Both soils presented predominant percentages of silicon, aluminum, and iron, coherent with their lateritic nature and mineralogical composition. CEC values for the clayey sand and the clay are low, indicating non-active soils (lower than $200 \mathrm{mmolc} \cdot \mathrm{kg}^{-1}$ ), which is common for Brazilian lateritic soils [49] due to the covering of clay minerals by iron and aluminum oxides. Similarly, the $\mathrm{pH}$ values correspond to acid soils, which is typical of lateritic soils.

\subsubsection{Geotechnical}

The geotechnical characterization of soils and mixtures is presented in Table 10. Addition of WTS to the soils did not significantly alter the particle size distribution (PSD), or else caused some of the mixtures to present only a slight increment in fines content compared 
with that of the natural soil, which may be explained by the low solids content added to the soils (varying from $3.4 \%$ to $13.9 \%$ ).

All soil:WTS mixtures presented higher liquid limits and plasticity indexes with increasing WTS content. WTS addition, however, dislocated the mixtures in Casagrande's plasticity chart parallel to or crossing downwards the A-line. Since both WTSs were not active, they did not impart cohesive behavior to the soils.

Table 10. Geotechnical characterization of Botucatu clayey sand and Campinas clay.

\begin{tabular}{|c|c|c|c|c|c|c|c|c|}
\hline Material & $w_{L}(\%)$ & PI (\%) & $\mathrm{G}_{\mathrm{s}}$ & Clay Fraction (\%) & Fines $(\%)$ & Sand $(\%)$ & OM (\%) & USCS \\
\hline $\begin{array}{l}\text { Botucatu clayey } \\
\text { sand-sample } 1\end{array}$ & 31 & 14 & 2.69 & 24.4 & 34.2 & 65.8 & - & SC \\
\hline BC5:1 & 32 & 14 & 2.71 & 26.8 & 36.1 & 63.9 & - & SC \\
\hline BC4:1 & 32 & 15 & 2.70 & 23.9 & 32.2 & 67.8 & - & SC \\
\hline BC3:1 & 33 & 16 & 2.69 & 27.1 & 36.6 & 63.4 & - & SC \\
\hline $\begin{array}{l}\text { Botucatu clayey } \\
\text { sand-sample } 2\end{array}$ & 25 & 8 & 2.80 & 28.9 & 35.3 & 64.7 & 3.5 & SC \\
\hline BT5:1 & 39 & 18 & 2.72 & 26.8 & 36.8 & 63.2 & - & SC \\
\hline BT4:1 & 44 & 19 & 2.70 & 26.1 & 38.8 & 61.2 & - & SC \\
\hline BT3:1 & 52 & 23 & 2.68 & 28.1 & 38.7 & 61.3 & - & SM \\
\hline Campinas clay & 45 & 18 & 2.98 & 52.0 & 78.1 & 21.9 & 11.7 & CL \\
\hline CC $4: 1$ & 46 & 18 & 2.98 & 44.7 & 80.1 & 19.9 & - & ML \\
\hline CC3:1 & 50 & 16 & 2.98 & 47.9 & 80.5 & 19.5 & - & ML-MH \\
\hline CC2:1 & 63 & 27 & 2.98 & 45.0 & 80.8 & 19.2 & - & $\mathrm{MH}$ \\
\hline СТ3:1 & 61 & 23 & 2.95 & 49.6 & 79.1 & 20.9 & - & $\mathrm{MH}$ \\
\hline CT2:1 & 77 & 34 & 2.94 & 52.0 & 81.9 & 18.1 & - & $\mathrm{MH}$ \\
\hline CT1.5:1 & 90 & 36 & 2.92 & 48.0 & 79.7 & 20.3 & - & $\mathrm{MH}$ \\
\hline
\end{tabular}

Note: $\mathrm{w}_{\mathrm{L}}=$ liquid limit, $\mathrm{PI}=$ plasticity index, $\mathrm{G}_{\mathrm{S}}=$ specific gravity of grains, $\mathrm{OM}=$ organic matter, USCS = Unified System of Soil Classification.

\subsection{Characterization of Additives and Additive:Soil Mixtures \\ 3.3.1. Chemical and Mineralogical}

The chemical composition of both additives obtained by X-ray fluorescence is presented in Table 11, while chemical parameters are presented in Table 12. The mineralogical analysis shows that lime is composed of calcite and portlandite. Portlandite derives from the calcination of carbonate rocks from Minas Gerais, Brazil, and calcite derives from noncalcinated rock or carbonatation of lime. Rock powder presents quartz, albite, microcline, phlogopite, amphibolite, and kaolinite, all of them minerals typical of granitic-gneissic rocks. The presence of kaolinite indicates that the rock was chemically weathered, even though the particles looked as if they came from sound rock.

Table 11. Chemical composition of lime and rock powder (percentage by dry mass).

\begin{tabular}{ccc}
\hline Oxide & Lime & Rock Powder \\
\hline $\mathrm{SiO}_{2}$ & 0.35 & 64.5 \\
$\mathrm{Al}_{2} \mathrm{O}_{3}$ & 0.08 & 14.0 \\
$\mathrm{Fe}_{2} \mathrm{O}_{3}$ & 0.98 & 4.83 \\
$\mathrm{MnO}$ & 0.01 & 0.10 \\
$\mathrm{MgO}$ & 0.35 & 1.45 \\
$\mathrm{CaO}$ & 68.2 & 3.09 \\
$\mathrm{Na}_{2} \mathrm{O}$ & $<0.001$ & 3.88 \\
$\mathrm{~K}_{2} \mathrm{O}$ & 0.03 & 4.68 \\
$\mathrm{TiO}_{2}$ & $<0.001$ & 0.76 \\
$\mathrm{P}_{2} \mathrm{O}_{5}$ & 0.08 & 0.28 \\
\hline
\end{tabular}

The lime used in this investigation was composed mostly of calcium, with a low percentage of impurities. The high value of loss-on-ignition can be explained by the fact 
that it is a hydrated lime. The $\mathrm{pH}$ value is inside the usual range for hydrated lime (12-13). The high value of CEC may be due to the experimental method based on exchangeable bases, which interpreted the high concentration of calcium as adsorbed cations.

Rock powder is mostly composed of silicon and aluminum, which are the main elements of the rock-forming minerals. Loss-on-ignition is low as expected for a granitic rock. Rock powder is also alkaline due to the high content of alkaline metals $(\mathrm{Na}, \mathrm{K})$ and alkaline earth metals $(\mathrm{Ca}, \mathrm{Mg})$ in its composition. The low value of $\mathrm{CEC}$ for the rock powder is coherent with the composing minerals, none of which are very active.

Table 12. Chemical parameters of lime and rock powder.

\begin{tabular}{|c|c|c|}
\hline Parameter & Lime & Rock Powder \\
\hline $\mathrm{pH}\left(\right.$ in $\left.\mathrm{H}_{2} \mathrm{O}\right)$ & 12.2 & 9.5 \\
\hline $\mathrm{pH}\left(\mathrm{KCl} 1 \mathrm{~mol} \cdot \mathrm{L}^{-1}\right.$ solution $)$ & 12.5 & 8.5 \\
\hline$\Delta \mathrm{pH}$ & 0.3 & -1.0 \\
\hline $\mathrm{K}^{2+}\left(\right.$ mmolc $\left.\cdot \mathrm{kg}^{-1}\right)$ & 4.1 & 24.9 \\
\hline $\mathrm{Ca}^{+}\left(\right.$mmolc $\left.\cdot \mathrm{kg}^{-1}\right)$ & 745 & 22 \\
\hline $\mathrm{Mg}^{2+}\left(\mathrm{mmolc} \cdot \mathrm{kg}^{-1}\right)$ & 2 & 5 \\
\hline $\mathrm{Na}^{+}\left(\right.$mmolc $\left.\cdot \mathrm{kg}^{-1}\right)$ & - & - \\
\hline $\mathrm{Al}^{3+}\left(\right.$ mmolc $\left.\cdot \mathrm{kg}^{-1}\right)$ & 0 & 0 \\
\hline $\mathrm{H}^{+}+\mathrm{Al}^{3+}\left(\mathrm{mmolc} \cdot \mathrm{kg}^{-1}\right)$ & 0 & 3 \\
\hline $\begin{array}{l}\text { Exchangeable bases } \\
\left(\mathrm{mmolc} \cdot \mathrm{kg}^{-1}\right)\end{array}$ & 751.1 & 51.9 \\
\hline CEC $\left(\right.$ mmolc $\left.\cdot \mathrm{kg}^{-1}\right)$ & 751.1 & 54.9 \\
\hline Base saturation (\%) & 100 & 95 \\
\hline Aluminum saturation (\%) & 0 & 0 \\
\hline Organic matter $(\%)$ & 0.2 & 1.1 \\
\hline Organic carbon $(\%)$ & - & - \\
\hline
\end{tabular}

$\overline{\mathrm{CEC}}=$ cation exchange capacity.

\subsubsection{Geotechnical}

The geotechnical characterization of the additives and additive:WTS mixtures is presented in Table 13.

Table 13. Geotechnical characterization of additives and additive:WTS mixtures.

\begin{tabular}{|c|c|c|c|c|c|c|c|c|}
\hline Material & WTS Content (\%) & $w_{L}(\%)$ & PI (\%) & $\mathrm{G}_{\mathrm{s}}$ & Clay Fraction (\%) & Fines $(\%)$ & Sand (\%) & USCS \\
\hline Lime (L) & & 61 & 17 & 2.44 & $33.5^{(2)}$ & $98.9^{(2)}$ & $1.1^{(2)}$ & $\mathrm{MH}$ \\
\hline LC1:1 & 28.6 & 58 & 16.9 & $2.55^{(1)}$ & - & - & - & $\mathrm{MH}$ \\
\hline LC1.2:1 & 25.0 & - & - & $2.54^{(1)}$ & - & - & - & $\mathrm{MH}$ \\
\hline LC1.3:1 & 22.2 & - & - & $2.53^{(1)}$ & - & - & - & $\mathrm{MH}$ \\
\hline $\begin{array}{c}\text { LC1.5:1 } \\
\text { Rock }\end{array}$ & 20.0 & 56.1 & 17.9 & $2.53^{(1)}$ & - & - & - & $\mathrm{MH}$ \\
\hline $\begin{array}{l}\text { powder } \\
\text { (RP) }\end{array}$ & $\mathrm{NP}$ & NP & NP & 2.67 & 4 & 20 & 79 & $\mathrm{SM}$ \\
\hline RPC2.1:1 & 14.3 & NP & NP & $2.71^{(1)}$ & - & - & - & SM \\
\hline RPC3:1 & 10.0 & NP & NP & $2.70^{(1)}$ & - & - & - & SM \\
\hline RPC4:1 & 7.4 & NP & NP & $2.69^{(1)}$ & 7.1 & 14.8 & 65.5 & SM \\
\hline RPC5:1 & 5.9 & NP & NP & $2.69^{(1)}$ & - & - & - & $\mathrm{SM}$ \\
\hline
\end{tabular}

Note: $\mathrm{w}_{\mathrm{L}}=$ liquid limit, $\mathrm{PI}=$ plasticity index, $\mathrm{G}_{\mathrm{S}}=$ specific gravity of grains, $\mathrm{OM}=$ organic matter, USCS = Unified System of Soil Classification, NP = non-plastic. ${ }^{(1)}$ Weighted average of the specific gravity of grains of WTS and additive. ${ }^{(2)}$ Grain size distribution for lime obtained by laser diffraction granulometer from Helos Sympatec.

Lime PSD could not be determined by sedimentation (hydrometer) since lime flocculates in contact with water. A laser diffraction granulometer test showed that the lime is a fine sand with $48.3 \%$ fines. According to the consistency limits, lime and the lime:WTS mixtures were classified as MH (elastic silt). Rock powder has $20 \%$ non-plastic fines. Rock powder and rock powder:WTS mixtures were classified as silty sands (SM). 


\subsection{Geotechnical Properties of Soils and Soil:WTS Mixtures \\ 3.4.1. Compaction}

The results of the compaction tests show that the maximum dry unit weight decreases and the optimum water content increases with WTS addition, i.e., at the optimum compaction point, the void ratio and the water content of the mixture are higher than those of the soil. These alterations are more evident and proportional with increasing WTS content, so that correlations between maximum dry unit weight and WTS content, and between optimum water content and WTS content, can be established. Compaction parameters of BC and BT mixtures as a function of WTS content are presented in Figure 3, while Figure 4 shows compaction parameters as a function of WTS content for CC and CT mixtures. While the general rule of thumb requires a minimum of 10 points for an accurate estimate of a linear regression, a lower number may suffice when a high $R^{2}$ is expected, and/or error is small, and/or the aim is merely to obtain a general trend. The obtained determination coefficients $R^{2}$ indicate that the variation of the dependent variables, maximum dry unit weight and optimum water content, can indeed be explained by the variation of the independent variable sludge content. More experimental points would of course improve the estimate. Nonetheless, we believe the presented correlations may in themselves be enough to determine the ideal mixture of soil and WTS to be used in the field. Therefore, the overall behavior of any new pairing of soil and WTS may be determined by a few compaction tests.
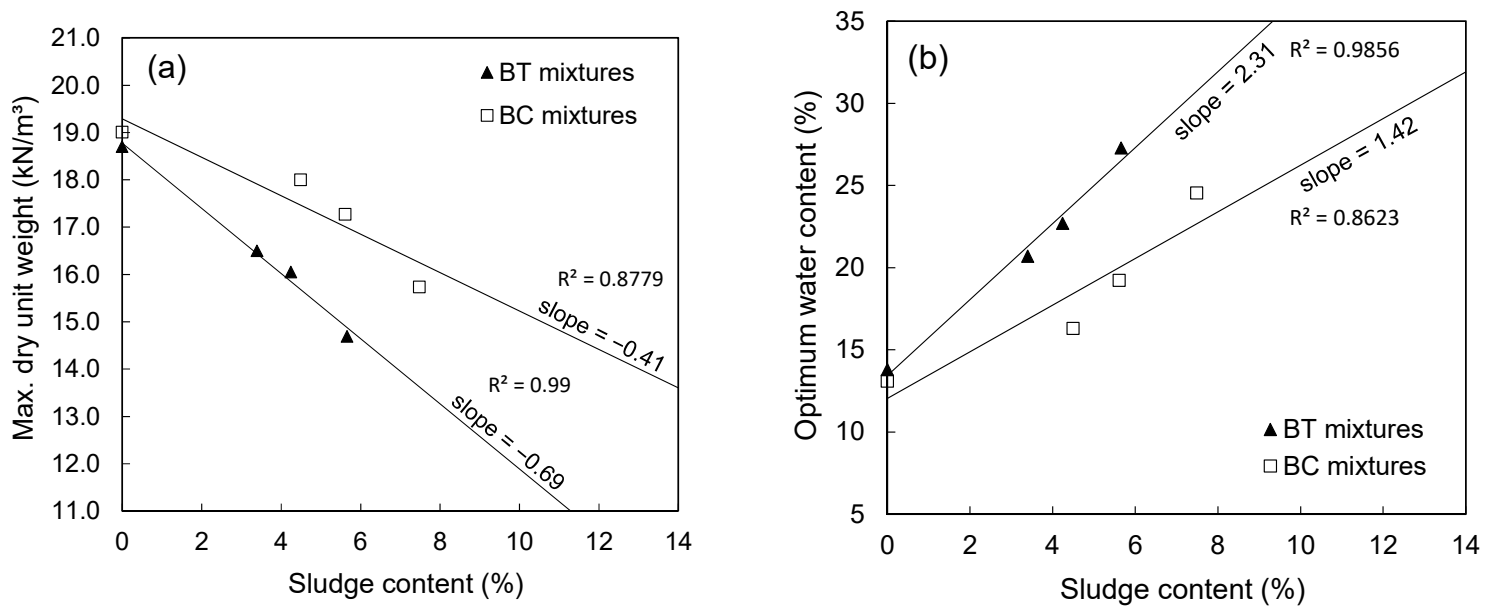

Figure 3. Compaction parameters as a function of WTS content for BC and BT mixtures: (a) Maximum dry unit weight; (b) Optimum water content.
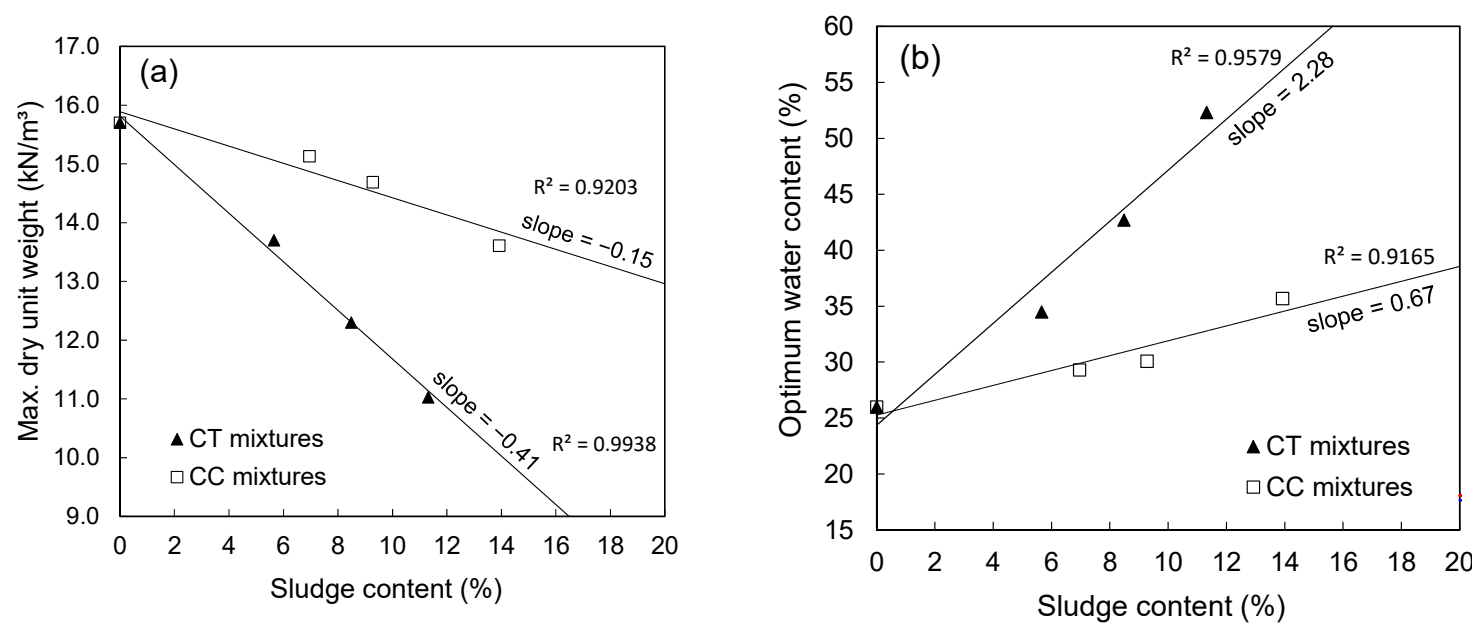

Figure 4. Compaction parameters as a function of WTS content for CC and CT mixtures: (a) Maximum dry unit weight; (b) Optimum water content. 
Some traces resulted in mixtures wet-of-optimum, and therefore were of limited workability. However, drying the mixture prior to compaction causes the maximum dry unit weight to increase and the optimum water content to decrease. These alterations are proportional to the desiccation ratio, so that a correlation between the compaction parameters and the desiccation ratio can be established. Figure 5 shows the recovery of compaction parameters as a function of desiccation ratio for all the mixtures. Since air drying mixtures is much faster than air drying WTS, these correlations may indicate the use of mixtures with higher WTS content that, once air-dried to a certain desiccation ratio, may show a good performance in the field, comparable with that of soil.
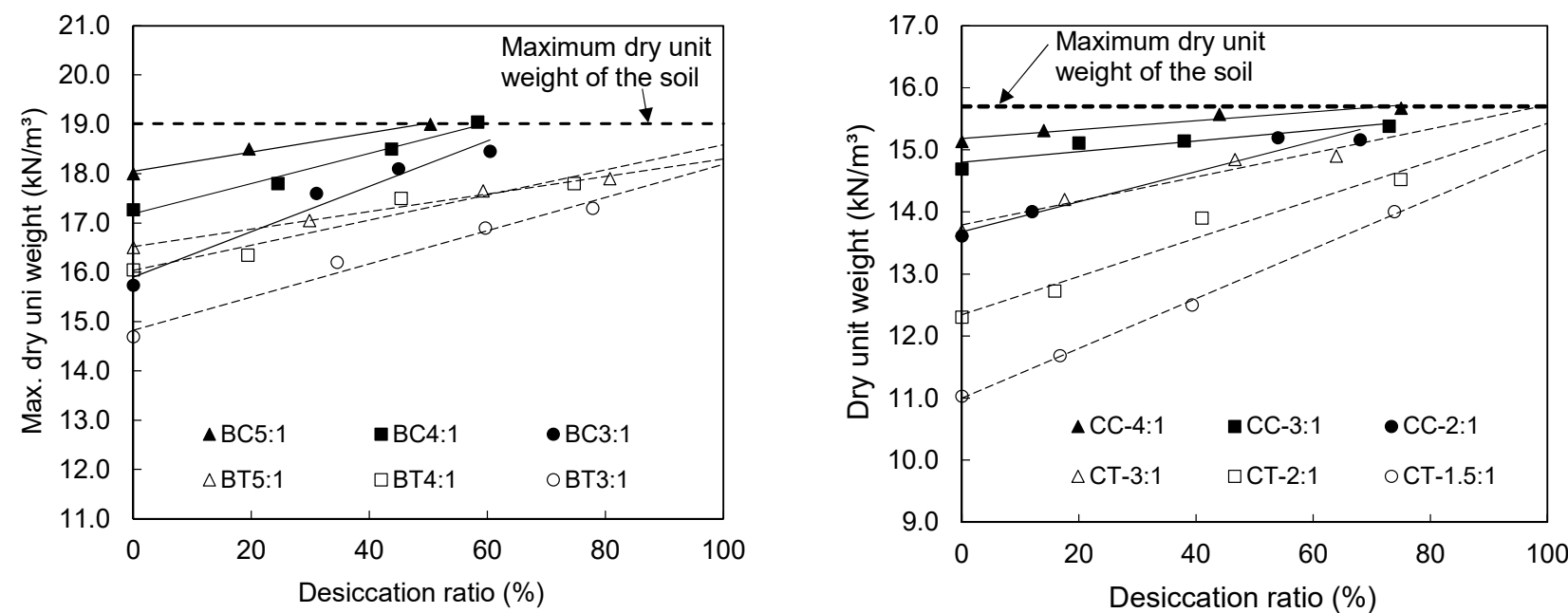

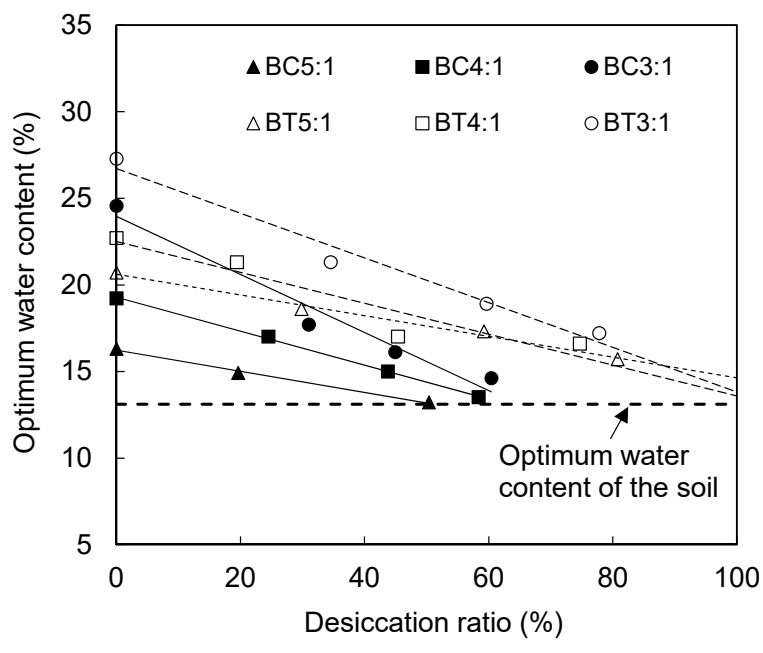

(a)

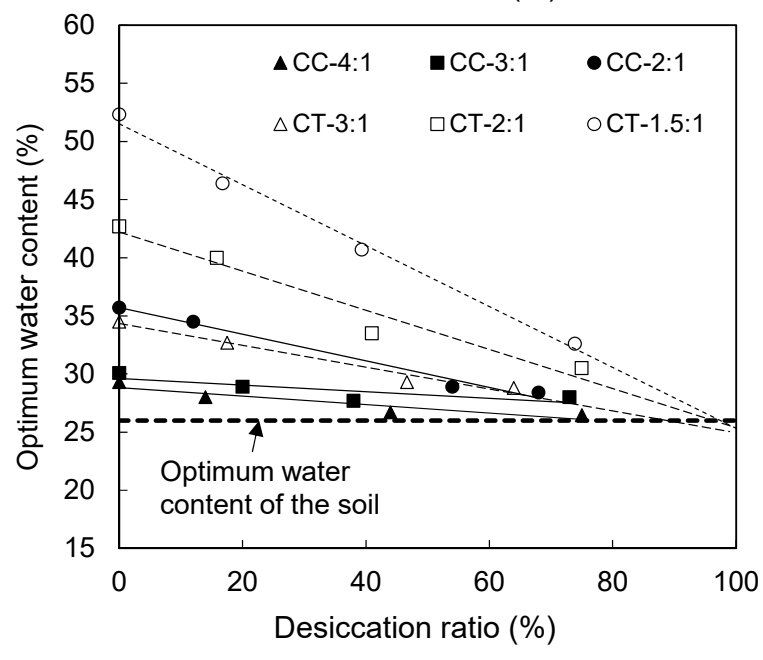

(b)

Figure 5. Maximum dry unit weight and optimum water content as a function of desiccation ratio: (a) BC and BT mixtures; (b) CC and CT mixtures.

\subsubsection{Shear Strength}

The long-term stability of embankments is usually analyzed for drained conditions, i.e., effective stresses. The shear strength of the mixtures in terms of effective stresses obtained from triaxial tests was compared with shear strengths in a database of Brazilian soils used for the construction of large earth dams. These embankments have shown satisfactory stability and deformation behavior over decades. Figure 6 shows the strength envelopes of the mixtures compared with the soil envelopes from the database. Clearly, the mixtures presented higher shear strength than the soils from the database for confining (normal) stresses higher than circa $80 \mathrm{kPa}$. Most mixtures presented a friction angle $\phi^{\prime}$ slightly 
higher than that of the natural soil. Addition of a clayey material with high plasticity limit was expected to reduce the friction angle; however, WTS fines were elastic (both WTSs were located below the A-line in Casagrande's plasticity chart). Furthermore, values of friction angle higher than $40^{\circ}$ have been reported for several WTSs [21,50]. Mixtures of zeolite and WTS were also reported to exhibit an increase in $\phi^{\prime}$ with increasing WTS content [51]. The increase in the friction angle was accompanied by a decrease in the cohesion with increasing WTS content, resulting, for each soil, in a single envelope for the different mixtures with each WTS, as shown in Figure 6, with a determination coefficient $R^{2}$ higher than 0.98 .

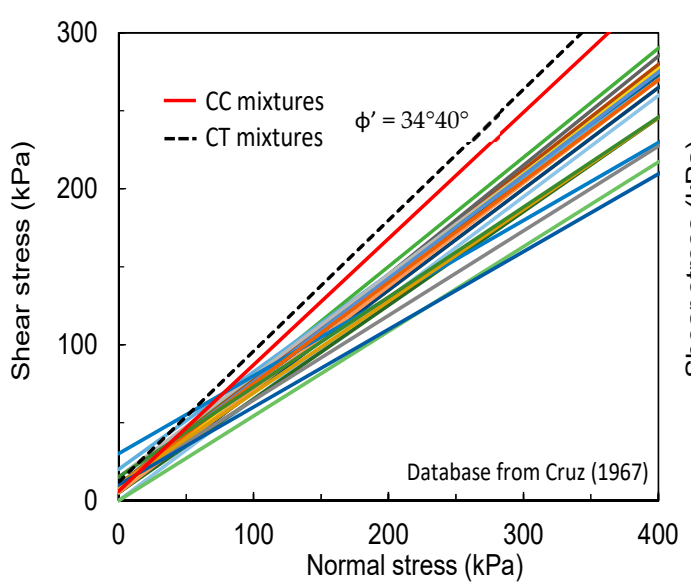

(a)
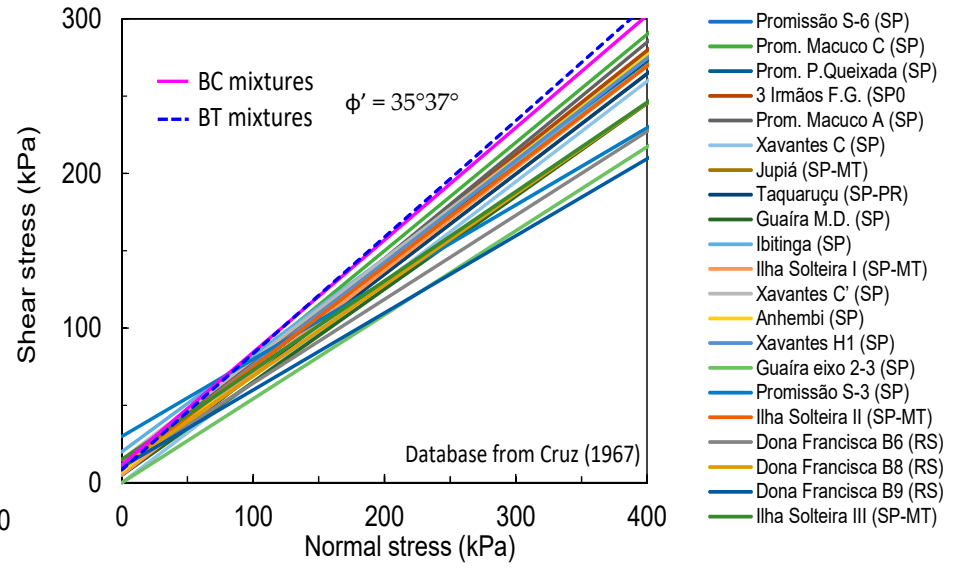

(b)

Figure 6. Shear strength envelopes comparison: (a) CC and CT mixtures; (b) BC and BT mixtures.

For the analysis of end-of-construction stability of embankments, the undrained shear strength must be considered for design purposes. The specification of a minimum undrained shear strength is generally governed by stability or trafficability. According to [52], a range of 50 to $60 \mathrm{kPa}$ is often considered to be an acceptable value for satisfactory equipment maneuvering without soil rutting, while [53] cites a minimum undrained strength of 40 to $50 \mathrm{kPa}$ as typically required for earthworks. For daily cover in sanitary landfills, a minimum undrained shear strength of 10 to $20 \mathrm{kPa}$ is required to assure easy spreading and workability of the material [20,52].

Figure 7 shows the as-compacted undrained shear strength $s_{u}$ (unsaturated) from UC tests compared with the undrained shear strength $\mathrm{s}_{\mathrm{u}}$ (saturated) from CU tests carried out with $50 \mathrm{kPa}$ confining pressure. The mixtures were compacted at their mixing moisture, i.e., with no previous drying. WTS addition clearly decreases the undrained shear strength. However, most mixtures answered to the criterion of $\mathrm{s}_{\mathrm{u}}$ equal or higher than $50 \mathrm{kPa}$.

\subsubsection{Permeability and Deformability}

Results of oedometric compression tests for soils and mixtures are presented in Table 14. In Table 15, permeability of soils and mixtures are presented as ranges since tests were carried out with several different confining pressures (50 to $200 \mathrm{kPa}$ ) and hydraulic gradients (10 to 50$)$. 
Table 14. Results of oedometric compression tests for soils and mixtures.

\begin{tabular}{ccc}
\hline Material & $\mathbf{C}_{\mathrm{c}} / \mathbf{( 1 + \mathbf { e } _ { \mathbf { 0 } } )}$ & $\mathbf{C}_{\mathbf{e}} /\left(\mathbf{1}+\mathbf{e}_{\mathbf{0}}\right)$ \\
\hline Botucatu clayey sand & 0.048 & 0.014 \\
BC mixtures & $0.084-0.110$ & $0.012-0.020$ \\
BT mixtures & $0.110-0.142$ & $0.016-0.030$ \\
Campinas clay & 0.103 & 0.022 \\
CC mixtures & $0.113-0.167$ & $0.014-0.023$ \\
CT mixtures & $0.138-0.189$ & $0.014-0.025$
\end{tabular}

Note: $\mathrm{C}_{\mathrm{c}}=$ compression index, $\mathrm{C}_{\mathrm{e}}=$ expansion index, $\mathrm{e}_{0}=$ initial void ratio.

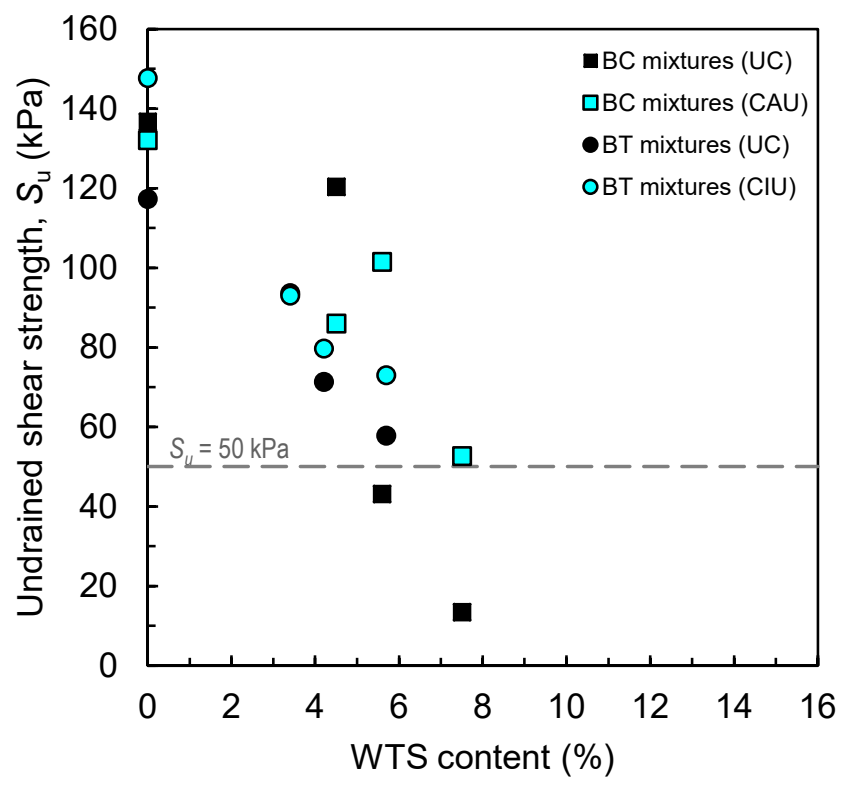

(a)

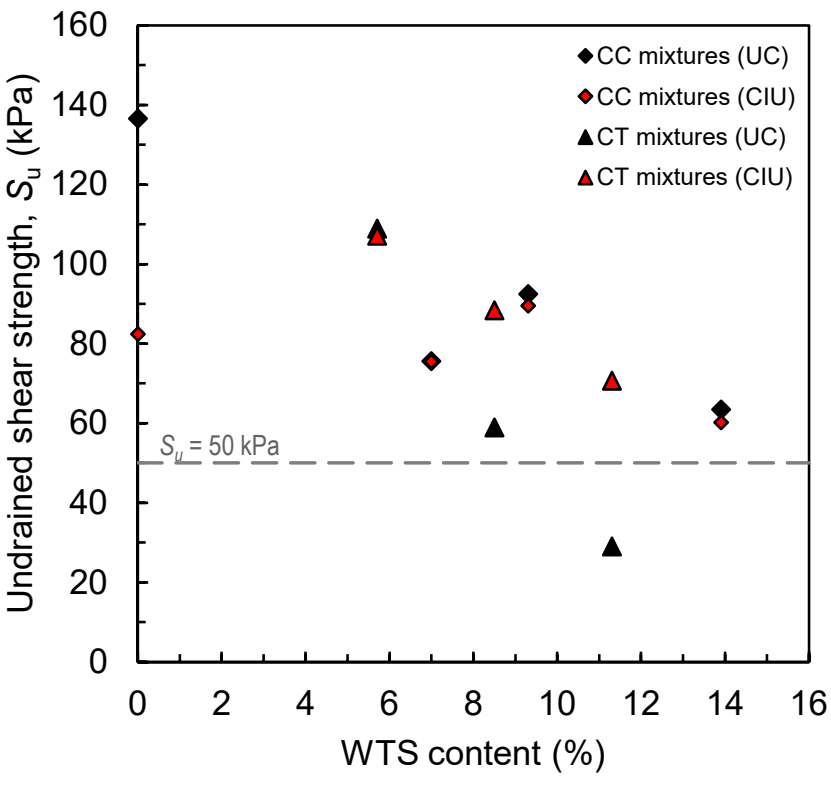

(b)

Figure 7. Undrained shear strength as a function of WTS content obtained by triaxial compression tests (saturated) and unconfined compression tests (as-compacted, unsaturated): (a) BC and BT mixtures; (b) CC and CT mixtures.

Table 15. Hydraulic conductivity of soils and mixtures.

\begin{tabular}{cc}
\hline Material & Hydraulic Conductivity K $\mathbf{~ m} / \mathbf{s})$ \\
\hline Botucatu clayey sand & $10^{-8}-10^{-6}$ \\
BC mixtures & $10^{-9}-10^{-6}$ \\
BT mixtures & $10^{-10}-10^{-8}$ \\
Campinas clay & $10^{-9}-10^{-8}$ \\
CC mixtures & $10^{-10}-10^{-9}$ \\
CT mixtures & $10^{-10}-10^{-9}$ \\
\hline
\end{tabular}

Most of the mixtures presented low to medium compressibility (compression index varying from 0.10 to 0.40 ). In comparison, some residual soils used for highway embankments in São Paulo State present compression index values ranging between 0.16 and 0.44 with an average of 0.31 [54]. In general, the average compression index of compacted Brazilian residual soils is about 0.15 . The compression coefficients (compression index $\mathrm{C}_{\mathrm{c}}$ divided by $1+$ initial void ratio $\mathrm{e}_{0}$ ) of $\mathrm{BC}$ and BT mixtures were 1.8 to 3 times that of B soil, and of CC and CT mixtures, they were 1.1 to 1.8 times that of $C$ soil; however, all values are inside an acceptable range for general earthworks. The same observation is valid for the expansion coefficients of the mixtures as compared with those of the soils.

Table 15 shows that WTS addition to both soils caused a reduction in hydraulic conductivity, indicating the possibility of using the mixtures with permeability lower than 
$10^{-9} \mathrm{~m} / \mathrm{s}$ as an adequate material for the construction of compacted clay liners (CCLs) or other impermeabilizing functions.

\subsection{Geotechnical Properties of Additive:WTS Mixtures}

\subsubsection{Compaction}

Compaction parameters of lime:WTS and rock powder:WTS mixtures as a function of WTS content are presented in Figure 8. The mixtures were air-dried to the hygroscopic water content, and the compaction test was carried out with increasing water contents. Increase in WTS addition caused a decrease in maximum dry unit weight of rock powder:WTS mixtures and an increase in maximum dry unit weight of lime:WTS mixtures, whereas the opposite trends were observed for the optimum water content. Rock powder:WTS mixtures become more porous and more humid at the optimum compaction point with increasing WTS content, while lime:WTS become slightly denser and less humid.

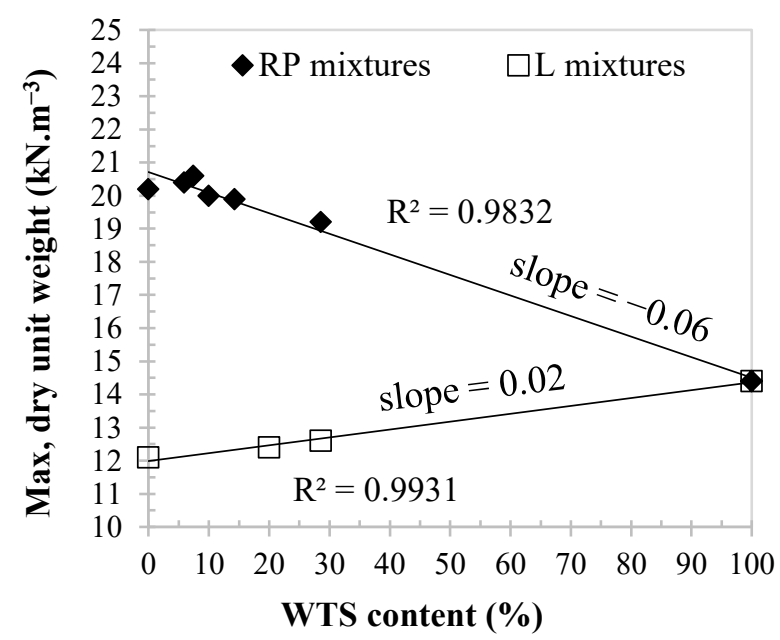

(a)

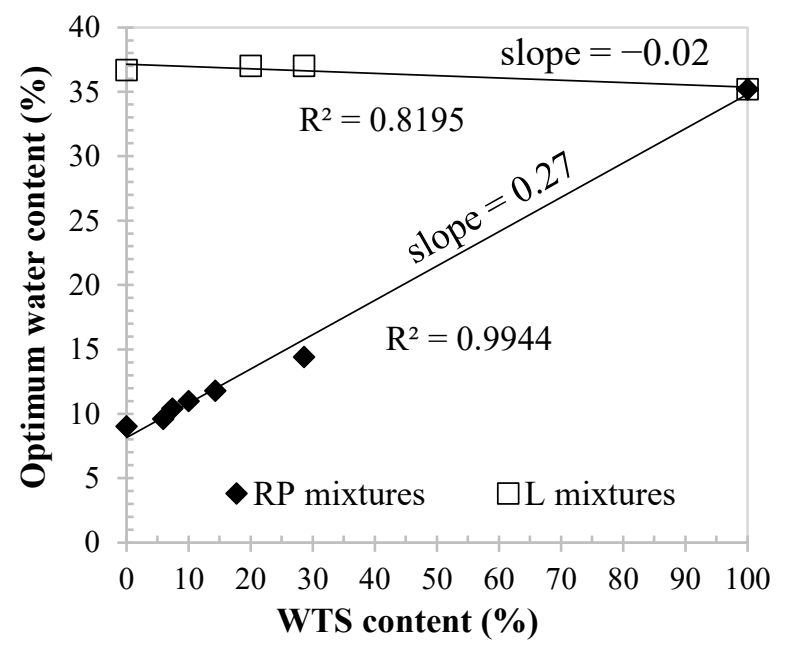

(b)

Figure 8. Compaction parameters as a function of WTS content for lime:WTS and rock power-WTS mixtures: (a) Maximum dry unit weight; (b) Optimum water content.

\subsubsection{Unconfined Compression}

The unconfined compression tests were carried out with mixtures compacted at asmixed water content. The undrained shear strength of additive:WTS mixtures as a function of WTS is presented in Figure 9. During the unconfined compression tests with lime:WTS mixtures, the shear stress increased monotonically with the axial strain, and no peak was observed, except for the mixture with $20.0 \%$ WTS content. Accordingly, the stress correspondent to the axial strain of $15 \%$ (maximum) was adopted as a failure criterion. For the rock powder:WTS mixtures, the stress-strain curves presented a peak value, except for WTS content of $14.3 \%$, in which case the stress for $15 \%$ axial strain was adopted as the failure threshold.

For the lime:WTS mixtures, the higher the WTS content, the lower is the undrained shear strength (Figure 9a), because the mixtures become less dense and more humid. An exponential regression describes the $s_{\mathfrak{u}}$ curve of lime:WTS mixtures with a determination coefficient $R^{2}$ of 0.9307 . As already observed, this indicates a general trend, whereas a more precise regression would require more experimental points. Rock powder:WTS mixtures presented much lower undrained strength values than lime:WTS mixtures, which may be explained by both rock powder and WTS both being non-cohesive materials. The trend of the undrained shear strength curve (Figure $9 \mathrm{~b}$ ) of rock powder:WTS mixtures suggests that the optimum value of WTS content is $7.4 \%$, where the maximum $s_{u}$ is obtained. 


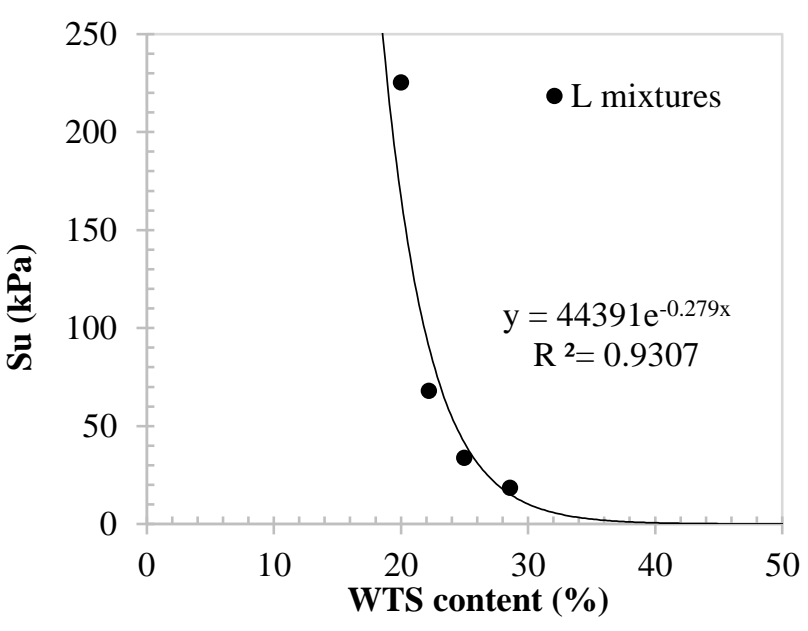

(a)

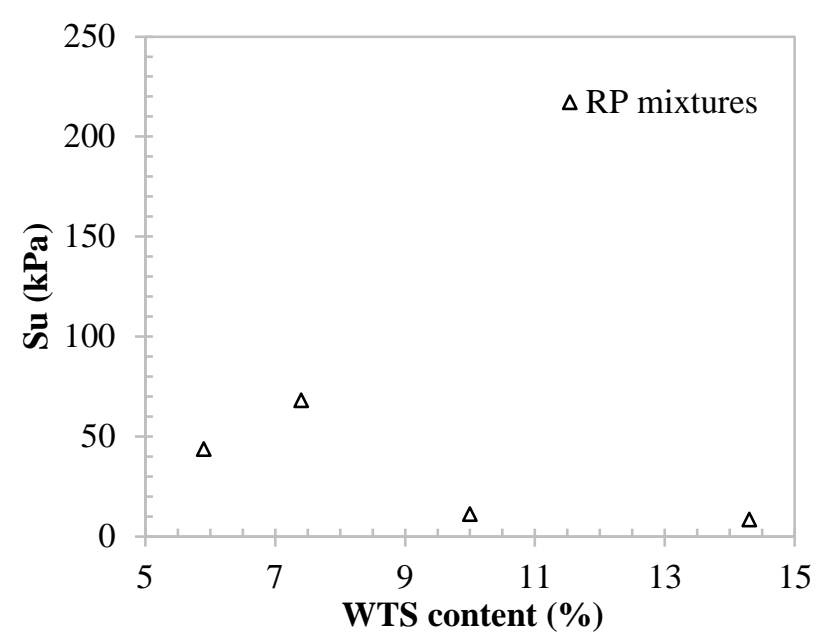

(b)

Figure 9. Undrained shear strength as a function of WTS content: (a) WTS-lime mixtures; (b) WTS-rock powder mixtures.

\subsection{Rheological Behavior of Cubatão-WTS}

Results of the rheometry flow tests are displayed in Figure 10. The complete shear history (two cycles of acceleration-deceleration) in Figure 10a shows that curves of acceleration and deceleration are different, i.e., a delay response of shear stress occurs, describing a hysteresis loop (area between acceleration and deceleration curves). Information about rheological behavior can be obtained by curve shape and/or hysteresis loop. Typically, only the second cycle is used to characterize the rheological behavior of materials because that is where the steady state of flow is assumed to have been reached. The second cycle is detailed in Figure 10b,c.

Some authors [55-58] have associated a positive hysteresis loop with thixotropic behavior (viscosity decreases with time) and a negative hysteresis loop with rheopectic behavior (viscosity increases with time). However, the hysteresis loop alone is not a faithful indicator of thixotropy or rheopexy since the effects of shear rate and time on viscosity may not be completely separated [56] in stepwise flow tests. At this point, results from the first cycle, related to a "very early age" behavior, are also important to characterize thixotropy and rheopexy. Figure 10d presents the results from the first cycle.

Figure 10b shows that shear stress for a certain value of shear rate is higher at deceleration than at acceleration, describing a negative hysteresis loop, i.e., rheopectic behavior (viscosity increases with time). The shape of the acceleration-deceleration curves describes shear thickening (or dilatant) behavior (viscosity increases with shear rate increase). A detailed analysis (Figure 10c) at low shear rates shows the opposite behavior: up to shear rate of $3 \mathrm{~s}^{-1}(180 \mathrm{rpm})$, shear stress is lower at deceleration than at acceleration for the same shear rate, describing a positive hysteresis loop, i.e., thixotropic (viscosity decreases with time) and shear thinning (viscosity decreases with shear rate increase) behavior.

Results of the first cycle of acceleration (Figure 10d) show that, despite the mixing procedure applied to WTS before the tests, a fast increase in shear stress occurred (0 to $340 \mathrm{~Pa}$ ), followed by an abrupt decrease ( 340 to $84 \mathrm{~Pa}$ ), while the shear rate increased ( 0 to $7.5 \mathrm{~s}^{-1}$, i.e., 0 to $450 \mathrm{rpm}$ ). This trend suggests that WTS recovered its agglomerated state between the end of the mixing procedure and the beginning of the test, so that a higher shear stress was needed to hold the shear rate. This interaction among particles being overcome, WTS became softer and more fluid when further sheared. Viscosity decreased due to shear rate increase but also due to the microstructure rearrangement, indicating a thixotropy behavior of WTS for early ages. The analysis of shear stress response during the first cycle of the flow test reinforced the interpretation based on the hysteresis loop: Cubatão-WTS probably presents shear thickening and rheopectic behavior for shear rates higher than $3 \mathrm{~s}^{-1}$ (180 rpm) and shear thinning and thixotropic behavior for shear rates 
lower than $3 \mathrm{~s}^{-1}$ (180 rpm). In other words, WTS viscosity decreases for low shear rates and increases for high shear rates.

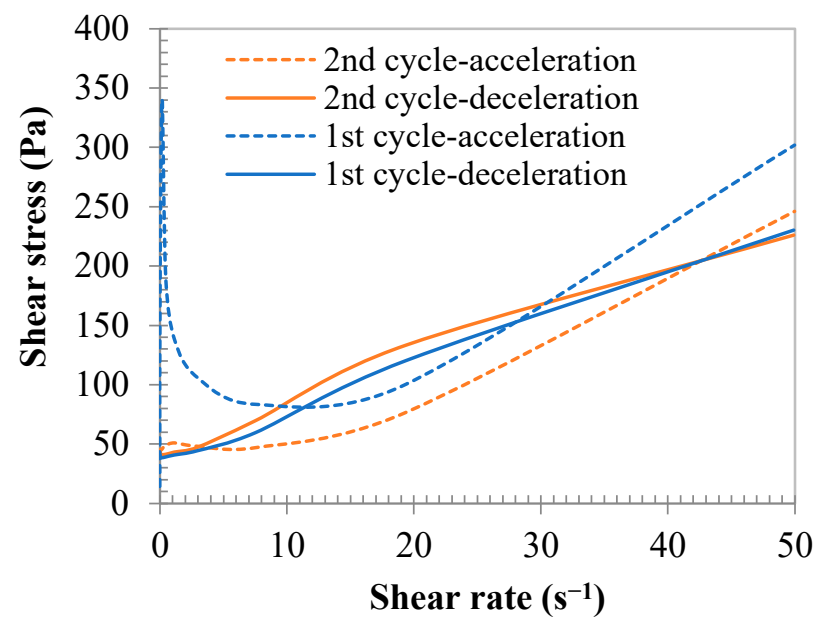

(a)

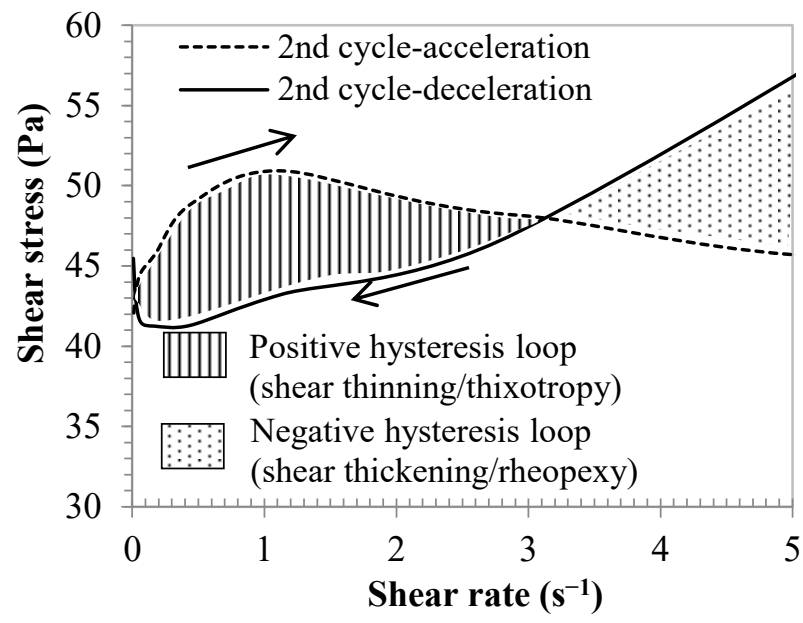

(c)

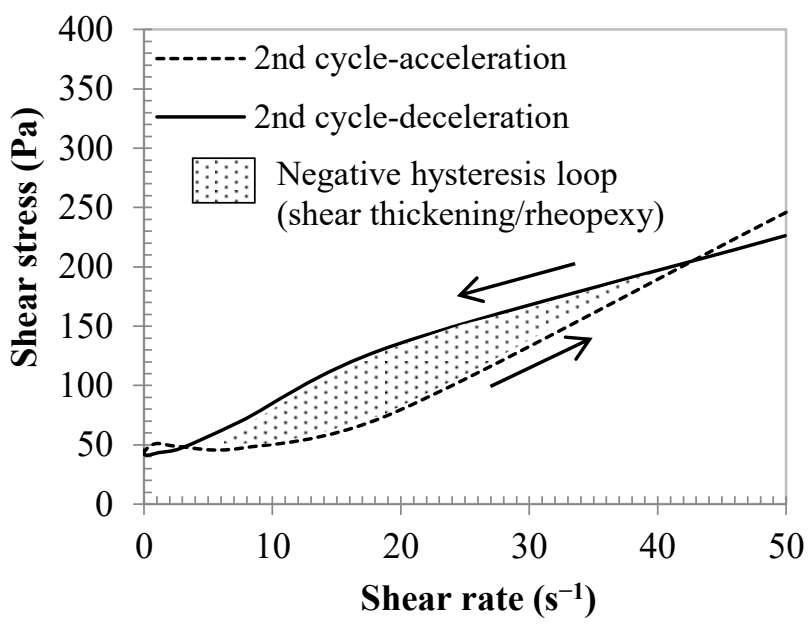

(b)

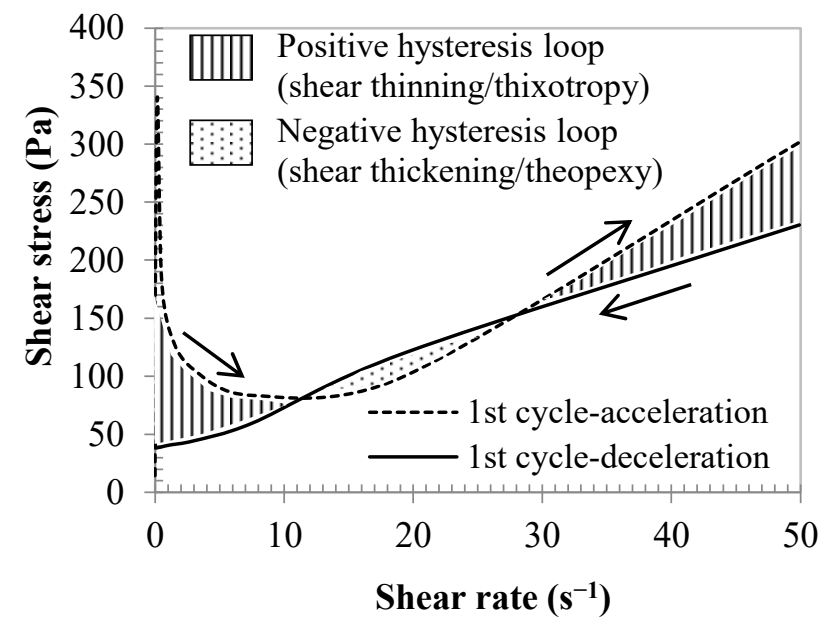

(d)

Figure 10. Results of flow tests for Cubatão-WTS: (a) Two cycles od acceleration-deceleration; (b) Second cycle; (c) Detail of second cycle at low shear rates; (d) First cycle. Source: Modified from Tsugawa et al. 2019.

Rheological behavior of WTS has been less investigated than that of wastewater and sewage sludges [59-61]. In practice, flow test results can help to predict WTS behavior during pumping, mixing, spreading, and transportation, as follows:

- According to the results of the second cycle (WTS already in flow), pumping at a shear rate lower than $180 \mathrm{rpm}$ is the best condition to avoid pipe clogging since viscosity tends to decrease. On the other hand, the first cycle indicates that a stress of $350 \mathrm{~Pa}$ is necessary to start WTS flow, i.e., pumping is more difficult to start than when WTS is already flowing. Therefore, mixing WTS is recommended before pumping.

- An interesting piece of equipment with which to mix WTS before pumping is the shallow soil mixer, whose arm is long enough to reach the bottom of a temporary storage cell. This equipment could also be used to pump instead of washing material at the bottom of the sedimentation basins.

- A concrete mixer may be an interesting alternative to produce additive:WTS mixtures, considering that it operates at $30 \mathrm{rpm}$ (at shear rates lower than $180 \mathrm{rpm}$ WTS viscosity decreases with shear rate, i.e., mixing is easier and demands less energy). 
- The environmental and economic costs related to the transportation of WTS by trucks can make reuse impracticable, particularly where long distances must be transposed to reach the end user. Apart from the high costs of fuel and vehicle maintenance, transportation by trucks also poses a great environmental concern due to contamination potential and greenhouse emissions. Underground transportation by a "sludge-pipe" connecting WTP and WTS processing plants can be promising for big generators, such as WTPs located in large cities where the lack of operational areas is an issue, and is already under debate at the Basic Sanitation Company of Sao Paulo State (SABESP), as presented at LETA 2021. Results from the rheological characterization of Cubatão-WTS strongly support the feasibility of transportation by pipeline. Transportation of WTS by pipeline without previous dewatering is also a possibility.

Rheological characterization can be a powerful tool to analyze reuse of WTS in geotechnical [28] and other applications, particularly focusing on WTS transportation.

\section{General Discussion}

Based on the results obtained by the experimental investigation, some aspects of WTS reuse in geotechnics should be further discussed in the light of economic, environmental, and social sustainability:

- This research used centrifuge dewatered WTS (at 20-25\% solids) and showed the influence of water content on the geotechnical behavior of soil:WTS and additive:WTS mixtures. Important questions concern: (1) the validity of extending the results for different dewatering methods, and (2) whether small municipalities in developing countries have the technical and economic conditions to dewater WTS. In answer to the first question, the range of $20-25 \%$ solids content is feasible to be achieved by different dewatering methods, albeit within different time spans. Electrodes associated with belt presses and geo-bags, geotextile-lined buckets submitted to vibration, geo-tubes and geo-bags, and even drying beds produce similar final solids contents. Polymers and vibration accelerate the dewatering process; however, the final product is still $\sim 25 \%$ solids. Electrokinetic flow does not depend on the grain size of the medium and was shown to be 10,000 times higher than hydraulic flow for bentonite; therefore, dewatering is much quicker, even though the final solids content of WTS will still fall within the $20-30 \%$ range. The second question has a very promising answer: a simple and cheap drying bed may achieve the desired solids range, as shown in six study cases of a modified drying bed design in use since 2004 in municipalities with a population lower or equal to 100,000 inhabitants (WTP production of 25-290 L/s), where the structuring gravel layer was substituted by non-woven geotextile; bed height was $50-80 \mathrm{~cm}$, WTS generation 2-32 L/month/inhabitant, dewatering cycle 30-40 days, and geotextile substitution 3-8 years. The information in this paragraph comes from unpublished state-of-the-art data conveyed during invited presentations at LETA 2021. The references and website are shown in the acknowledgments.

- The first step in waste management is the reduction in waste generation. Despite the reduction in WTS generation not being the subject of this paper, some suggestions arise from the experimental investigation: (1) improvement in the quality of raw water, discussed in the next paragraph; (2) employment of other treatment processes, e.g., electrocoagulation and electro-flocculation, which generate less sludge than the conventional complete cycle treatment [62]; (3) employing adequate equipment to mix and pump the material deposited at the bottom of the sedimentation basins instead of washing (i.e., using more water) might also reduce the quantity of generated WTS; (4) as discussed in the previous paragraph, usual dewatering methods produce WTS with very high residual water contents-to develop more efficient dewatering methods investigation is needed into the different states of water (free, interstitial, vicinal, and hydration) in WTS and the kinetics of water desorption.

- Sustainable solutions for WTS reuse are directly related to the quality of raw water, a point stressed in the presentations at LETA 2021. Discharge of domestic sewage and 
industrial effluents in water courses where raw water is captured brings chemical and biological risks (algae, cyanobacteria, protozoa, virus, pharmaceuticals, and hormones) that demand complementary processes and operations at the WTPs. A scanning of organic compounds additional to those presently demanded by the environmental regulations for WTS to assess the presence of pathogenic microorganisms, heavy metals, and halogenated compounds derived from chlorine and organic matter is recommended. Waste treatment and disposal, quality of raw water, water treatment, residue generated at the WTP, and, finally, reuse alternatives for WTS form a cycle. Attention and action in all these stages are necessary for the sustainable, healthy, and environment-friendly supply of potable water.

- Fundamental steps for WTS reuse in geotechnics are characterization, determination of geotechnical properties (sometimes adaptation of equipment and procedures are necessary because of the water content being much higher than that of soft soils), and assessment of environmental impacts based on WTS characteristics and on the intended applications. Characterization, as previously discussed, should be related to the desired use, and also environmental assessment should be based on the real conditions of the applied product for the evaluation of toxicity in the short and long terms. Due to the complexity of the many geotechnical applications for WTS, we suggest that WTS should be licensed as a byproduct for each different intended geotechnical application. Directives and protocols could then be made more direct and clearer, furthering the WTS's acceptance by environmental agencies, designers, constructors, and the population in general as a by-product.

- Directives for the approval of beneficial uses of waste are needed. Many developing countries still do not have regulations to declassify a residue as waste and reclassify it as a by-product. As an example, we mention the conditions that must be met according to the Portuguese regulation, article 44-A of the General Regime of Waste Management [62]: certainty of posterior utilization; can be directly used, without any process other than normal industrial practice; production must be an integrated part of a productive process; must meet the relevant requirements concerning environment and health protection and do not cause adverse impacts on the environment and public health. According to this directive, WTS used in soil:WTS and additive:WTS mixtures for geotechnical applications is a promising by-product.

- In this research, the use of WTS as a geomaterial has been proven to be technically acceptable and environmentally safe. However, a protocol for characterization should be followed for each WTS and each soil or additive to be mixed, i.e., each WTP must be treated individually. This is common practice in geotechnics, where soils and rocks are characterized for each project or work.

- Environmental sustainability of WTS reuse as here proposed is based on different aspects: (1) the partial substitution of soil by WTS, which is a major advantage for the preservation of natural resources in general, and particularly in countries whose economy is based on agrobusiness and where land is an asset; (2) the intended reuse does not require burning, incineration or any other activities that generate toxic releases to the environment; (3) the application of WTS mixed with local soil for general earthworks in municipalities avoids transportation over long distances; (4) the utilization of a sludge-pipe between large WTPs and WTS processing centers may reduce the carbon footprint as compared with overland transportation.

- WTS dewatering, transportation, and reuse should take into account the reduction in carbon footprint. This evaluation must be carried out by further investigations.

- The economic sustainability of waste reuse depends on public policies since fresh natural materials are generally preferred due to custom, lower costs, and security wherever communities do not feel environmentally pressed to reuse waste. On the other hand, the costs of an environmentally safe disposal of WTS, associated with fiscal incentives for the use of by-products, can make WTS reuse attractive, thus furthering 
the necessary, if not urgent, change from the habitual and harmful discharge of WTS in bodies of water.

- Waste reuse can be troublesome for those municipalities that cannot rely on qualified staff to attend to all the associated technical and legal issues. Private businesses should ideally play a crucial part in the valorization of WTS, buying WTS from WTPs as waste or by-product, processing it, and selling it to the end user. These businesses would obtain environmental licenses for the product and its intended uses, shouldering at least part of the technical and legal burden for the municipalities.

- Developing countries would greatly benefit from creating a database of characteristics of raw water and WTS characteristics to enhance WTS reuse.

- The social sustainability of the proposed WTS reuse alternatives relies on the opportunity to generate income by creating new jobs associated with the new products and WTS processing firms, the improvement of living standards and social equality since usually low-income communities are those most affected by water pollution, and the regaining of urban areas presently given to waste disposal.

\section{Conclusions}

The experimental investigation showed that soil:WTS mixtures are sound multipurpose geomaterials from a geomechanical point of view, considering permeability, shear strength, and deformability properties. Preliminary environmental tests indicate that they are also environmentally viable, even if further research is needed to reach definitive conclusions. Future work includes leaching tests, simulating practical conditions for each specific application and addressing other contaminants, such as microorganisms, pharmaceuticals, and hormones. Lime:WTS and rock powder:WTS mixtures can be used for applications with low soliciting stresses. However, minimum shear strength for earthworks could only be achieved at low sludge contents, requiring that the search continues for additives capable of creating good all-purpose geomaterials. The paper also highlights the importance of determining the properties of WTS and characterizing it in geological and rheological terms so that the possibilities of its sustainable reuse in developing countries can be assessed at all stages, from mixing and transportation to environmental licensing.

Author Contributions: Conceptualization, methodology, resources, writing-original draft preparation, writing-review and editing supervision, project administration, and funding acquisition, M.E.G.B.; methodology, first suggested by the M.E.G.B. and developed along the investigation by straight collaboration with J.K.T. and E.L.T.M. (Ph.D. students); investigation, by J.K.T. and E.L.T.M.; validation, formal analysis, and data curation, by the three authors in straight collaboration. All authors have read and agreed to the published version of the manuscript.

Funding: This research was funded by a joint funding program of FAPESP and SABESP, grant number 2013/50448-8, São Paulo Research Foundation (FAPESP); and scholarships: grant 2017/24056-6 and 2019/17183-7, São Paulo Research Foundation (FAPESP), CNPq 141589/2016-7 and 310801/2017-6, and CAPES 88887.368004/2019-00.

Institutional Review Board Statement: Not applicable.

Informed Consent Statement: Not applicable.

Data Availability Statement: This study did not use data or datasets supporting results other than those produced by research from the authors.

Acknowledgments: The authors would like to acknowledge the technical support given by Paulo Scarano Hemsi, Delma Mattos Vidal, Iara Maria Carneiro de Camargo, and Marcelo Kenji Miki during this research. The authors would also like to acknowledge precious however yet unpublished information conveyed by the lecturers at LETA 2021: Albuquerque, A. Characteristics and applications of water treatment sludge in Portugal; Urashima, D.; Vidal, D.; Lins, J. Dewatering in waste confinement system in geotextiles; Morita, D. Water treatment sludge: lessons learned and perspectives; Zuffo, C.K. Actions and challenges in research, development and innovation on the sanitation fiels: water treatment sludge; Tsugawa, J.K.; Fiore, F.A. Multiple characterizations of WTS for sutainable handling and destination; Müller, M. Dewatering of water treatment sludge in special draining container with geotextile refills; Castro, N. The use of geotube 
technology in the restoration of Kings Bay, Florida. Case studies and innovative solutions; Fontana, A.O.; Cordeiro, J.S.; Achon, C.L.; Barroso, M.M.; Reis, R.F. dos Water treatment sludge dewatering: successful experiences with drying beds implantation; Jones, C. Electrokinetic dewatering of sludge; Di Bernardo, L. The importance of raw water characteristics in the efficiency of dewatering of water treatment sludge in geotextiles. These presentations are available at https:/ / www.youtube.com/watch?v=Dd3UoXhDn7A\&t=2778s (17 June 2021), https:/ / www.youtube.com/watch?v=D2SBxoZRq-c\&t=166s (18 June 2021) and https: / / www.youtube.com/watch?v=NiFiIAF8ejo\&t=7186s (19 June 2021).

Conflicts of Interest: The authors declare no conflict of interest.

\section{References}

1. Richter, C.A. Tratamento de Lodos de Estações de Tratamento de Águas, 1st ed.; Edgard Blücher: São Paulo, Brazil, 2001.

2. Unesco. The United Nations World Water Development Report 2019: Leaving No One Behind; Unesco World Water Assessment Programme: Paris, France, 2019; Volume 96, ISBN 9789231003097.

3. United Nations. The 17 Goals. Available online: https:/ /sdgs.un.org/goals (accessed on 8 July 2021).

4. Garcia, S.S. Caracterização de Argamassas Auto-Compactáveis com Adição de Lamas Provenientes de uma ETA. Master's Thesis, Universidade de Beira Interior, Covilhã, Portugal, 2011.

5. Chen, H.; Ma, X.; Dai, H. Reuse of water purification sludge as raw material in cement production. Cem. Concr. Compos. 2010, 32, 436-439. [CrossRef]

6. Teixeira, S.R.; Santos, G.T.A.; Souza, A.E.; Alessio, P.; Souza, S.A.; Souza, N.R. The effect of incorporation of a Brazilian water treatment plant sludge on the properties of ceramic materials. Appl. Clay Sci. 2011, 53, 561-565. [CrossRef]

7. Benlalla, A.; Elmoussaouiti, M.; Dahhou, M.; Assafi, M. Utilization of water treatment plant sludge in structural ceramics bricks. Appl. Clay Sci. 2015, 118, 171-177. [CrossRef]

8. Godoy, L.G.G.; de Rohden, A.B.; Garcez, M.R.; Costa, E.B.; da Da Dalt, S.; Andrade, J.J. Valorization of water treatment sludge waste by application as supplementary cementitious material. Constr. Build. Mater. 2019, 223, 939-950. [CrossRef]

9. Uçaroglu, S.; Alkan, U. Composting of wastewater treatment sludge with different bulking agents. J. Air Waste Manag. Assoc. 2016, 66, 288-295. [CrossRef]

10. Chaves, V.T.; Morita, D.M.; Chao, I.R.S.; Contrera, R.C. Phosphorus recovery from sewage with a sustainable and low-cost treatment system. Water Sci. Technol. 2019, 80, 846-854. [CrossRef]

11. Razali, M.; Zhao, Y.; Bruen, M. Effectiveness of a drinking-water treatment sludge in removing different phosphorus species form aqueous solution. Sep. Purif. Technol. 2007, 55, 300-306. [CrossRef]

12. Krishna, K.C.B.; Aryal, A.; Jansen, T. Comparative study of ground water treatment plants sludges to remove phosphorous from wastewater. J. Environ. Manag. 2016, 180, 17-23. [CrossRef]

13. Elliot, H.A.; Dempsey, B.A.; Hamilton, D.W.; DeWolfe, J.R. Land Application of Water Treatment Sludges: Impact and Management; Foundation Report; American Water Works Association: Denver, CO, USA, 1990.

14. Cruz, C.L.B.M.; Santos, A.S.; Ritter, E. Study on the viability of incorporation of the water treatment plant sludge in the substrate for the production of native species to the Atlantic Forest (Brazil). In Proceedings of the 6th International Conference on Sustainable Solid Waste Management: NAXOS2018, Naxos Island, Greece, 13-16 June 2018; Volume 1, pp. 1-8.

15. Abo-El-Enein, S.A.; Shebl, A.; Abo El-Dahab, S.A. Drinking water treatment sludge as an efficient adsorbent for heavy metals removal. Appl. Clay Sci. 2017, 146, 343-349. [CrossRef]

16. Siswoyo, E.; Mihara, Y.; Tanaka, S. Determination of key components and adsorption capacity of a low cost adsorbent based on sludge of drinking water treatment plant to adsorb cadmium ion in water. Appl. Clay Sci. 2014, 97-98, 146-152. [CrossRef]

17. Petruzzelli, D.; Volpe, A.; Limoni, N.; Passino, R. Coagulants removal and recovery from water clarifier sludge. Water Res. 2000, 34, 2177-2182. [CrossRef]

18. Scalize, P.S.; Souza, L.M.D.; Albuquerque, A. Reuse of alum sludge for reducing flocculant addition in water treatment plants. Environ. Prot. Eng. 2019, 45, 57-70. [CrossRef]

19. Raghu, D.; Hsieh, H.-N.; Neilan, T.; Yih, C.-T. Water treatment plant sludge as landfill liner. In Proceedings of the Geotechnical Practice for Waste Disposal'87. A Specialty Conference, Ann Arbor, MI, USA, 15-17 June 1987; ASCE-American Society of Civil Engineers: New York, NY, USA, 1987; pp. 744-758.

20. Dos Santos Silva, A.; Hemsi, P.S. Efeito do teor de sólidos na resistência ao cisalhamento de um lodo de ETA visando seu uso em cobertura diária de aterros sanitários. In Proceedings of the XIX Congresso Brasileiro de Mecânica dos Solos e Engenharia Geotécnica-COBRAMSEG, Salvador, Brazil, 28 August-1 September 2018; ABMS, Ed.; ABMS: Salvador, Brazil, 2018.

21. Roque, A.J.; Carvalho, M. Possibility of using the drinking water sludge as geotechnical material. In Proceedings of the 5th ICEG Environmental Geotechnics: Opportunities, Challenges and Responsibilities for Environmental Geotechnics-Proceedings of the ISSMGE 5th International Congress, Cardiff, UK, 26-30 June 2006; Volume II.

22. Fortes, R.M.; Merighi, J.V.; Pauli, D.R.; Barros, M.A.L.; de Carvalo, M.H.; Menetti, N.C.; Barbosa, A.S., Jr.; Ribeiro, F.V.; Bento, B.B. Study of dry sludge from water treatment plant (WTP) in Taiaçupeba to use as compacted soil in earthwork ditches. In Proceedings of the 8th International Conference on the Bearing Capacity of Roads, Railways, and Airfields, Champain, IL, USA, 29 June-2 July 2009. 
23. Montalvan, E.L.T.; Boscov, M.E.G. Geotechnical parameters of mixtures of a tropical soil with water treatment sludge. In Proceedings of the Environmental Science and Engineering, Kaohsiung, Taiwan, 28 October-1 November 2019.

24. Santos, E.F.; Scapin, J.; Pinheiro, R.J.B. Relação entre o teor de lodo de ETA e parâmetros de compactação em misturas com solo siltoso da região de Santa Maria-RS. In Proceedings of the X Seminário de Engenharia Geotécnica do Rio Grande do Sul-GEORS2019, Santa Maria, Rio Grande do Sul, Brazil, 13-14 June 2019; pp. 1-9.

25. Babatunde, A.O.; Zhao, Y.Q. Constructive approaches toward water treatment works sludge management: An international review of beneficial reuses. Crit. Rev. Environ. Sci. Technol. 2007, 37, 129-164. [CrossRef]

26. Ahmad, T.; Ahmad, K.; Alam, M. Sustainable management of water treatment sludge through 3'R' concept. J. Clean. Prod. 2016, 124, 1-13. [CrossRef]

27. De Carvalho Gomes, S.; Zhou, J.L.; Li, W.; Long, G. Progress in manufacture and properties of construction materials incorporating water treatment sludge: A review. Resour. Conserv. Recycl. 2019, 145, 148-159. [CrossRef]

28. Tsugawa, J.K.; Romano, R.C.; Pileggi, R.G.; Boscov, M.E.G. Review: Rheology principles applied to geotechnical engineering. Appl. Rheol. 2019, 29, 202-221. [CrossRef]

29. Gy, P. Sampling for Analytical Purposes; Willey: Hoboken, NJ, USA, 1999.

30. Donagema, G.; Campos, D.; Calderano, S.; Teixeira, W.; Viana, J. Handbook of Soil Analysis Method, 3rd ed.; Embrapa Soils: Rio de Janeiro, Brazil, 2011.

31. O'Kelly, B.C.; Sivakumar, V. Water content determinations for peat and other organic soils using the oven-drying method. Dry. Technol. 2014, 32, 631-643. [CrossRef]

32. Cornwell, D.A.; Vandermeyden, C.; Dillow, G.; Wang, M. Landfilling of Water Treatment Plant COAGULANT Sludges; AWWA Research Foundation and American Water Works Association: Denver, CO, USA, 1992.

33. Basim, S.C. Physical and Geotechnical Characterization of Water Treatment Plant Residuals; New Jersey Institute of Technology: Newark, NJ, USA, 1999.

34. Watanabe, Y.; Komine, H.; Yasuhara, K.; Murakami, S. Batch leaching test focusing on clod size of drinking water sludge and applicability to long-term prediction using column leaching test. In Proceedings of the Geofrontiers 2011 Advances in Geotechnical Engineering, Dallas, TX, USA, 13 March 2011.

35. Montalvan, E.L.T.; Boscov, M.E.G. Geotechnical parameters of mixtures of a tropical soil with water treatment sludge. In Proceedings of the Environmental Science and Engineering Book Serie: Proceedings of the 8th International Congress on Environmental Geotechnics, Hangzhou, China, 28 October-1 November 2018; Springer: Singapore, 2019; Volume 1, pp. 235-242, ISBN 9789811322204.

36. Montalvan, E.L.T. Investigação do Comportamento Geotécnico de Misturas de Solo Arenosos com Lodo da Estação de Tratamento de Água do Município de Cubatão, SP. Master's Thesis, University of Sao Paulo, Sao Paulo, Brazil, 2016.

37. Güneyli, H.; Rüssen, T. Effect of length-to-diameter ratio on the unconfined compressive strength of cohesive soil specimens. Bull. Eng. Geol. Environ. 2016, 75, 793-806. [CrossRef]

38. Associação Brasileira de Normas Técnicas. ABNT-NBR 10004 Resíduos sólidos—Classificação; Associação Brasileira de Normas Técnicas: Rio de Janeiro, Brazil, 2004; p. 71.

39. Associação Brasileira de Normas Técnicas. ABNT-NBR 10006 Procedimento para Obtenção de Extrato Solubilizado de Resíduos Sólidos; Associação Brasileira de Normas Técnicas: Rio de Janeiro, Brazil, 2004; p. 3.

40. Associação Brasileira de Normas Técnicas. ABNT-NBR 10005 Procedimento para Obtenção de Extrato Lixiviado de Resíduos Sólidos; Associação Brasileira de Normas Técnicas: Rio de Janeiro, Brazil, 2004; p. 16.

41. Tsugawa, J.K.; Romano, R.C.; Pileggi, R.G.; Boscov, M.E.G. A rheological approach for the evaluation of geotechnical use of water treatment sludge. In Environmental Science and Engineering Book Serie: Proceedings of the 8th International Congress on Environmental Geotechnics; Springer: Singapore, 2019; Volume 1, pp. 264-272. ISBN 9789811322204.

42. Tsugawa, J.K.; Sabino, E.F.; Monte, R.; Boscov, M.E.G. Importance of composing representative samples according to the Theory of Sampling (TOS) for the reuse of water treatment sludge. In Proceedings of the XVI Pan-American Conference on Soil Mechanics and Geotechnical Engineering (XVI PCSMGE), Geotechnical Engineering in the XXI Century: Lessons Learned and Future Challenges, Cancun, Mexico, 17-20 November 2019; pp. 2450-2457.

43. Barroso, M.M. Influência das Micro e Macropropriedades dos Lodos de Estações de Tratamento de Águas no Desaguamento por Leito de Drenagem. Ph.D. Thesis, Universidade de São Paulo, Sao Paulo, Brazil, 2007.

44. Montalvan, E.L.T. Geotechnical Properties of Mixtures of Water Treatment Sludge and Residual Lateritic Soils from the State of São Paulo. Ph.D. Thesis, University of Sao Paulo, Sao Paulo, Brazil, 2021.

45. CETESB. Valores Orientadores Para Solo e Água Subterrânea. 2014. Available online: https://cetesb.sp.gov.br/aguassubterraneas/valores-orientadores-para-solo-e-agua-subterranea/ (accessed on 25 August 2021).

46. Higashi, R.J.; Camargo, C.I.M.; Boscov, M.E.G. Chemical Charateristics os Cubatão water Treament Sludge. In Proceedings of the First Meeting of Water Treatment Sludge-Connections for Technology Innovation (LETA2021), Online Event, 17-19 June 2021; Available online: https:/ / www.ggga.ita.br/Anais_LETA2021_comprimido.pdf (accessed on 25 August 2021).

47. Silva, A.R. Geotechnical Behavior of Mixtures of a Lateritic Clayey Sand and Sludge from the Water Treatment Plan Taiaçupeba, Suzano. Master's Thesis, University of Sao Paulo, São Paulo, Brazil, 2021.

48. Nogami, J.S.; Villibor, D.F. Pavimentação de Baixo Custo com Solos Lateríticos; Villibor: São Paulo, Brazil, 1995. 
49. Fadigas, F.D.S.; Amaral-Sobrinho, N.M.B.; Mazur, N.; Dos Anjos, L.H.C.; Freixo, A.A. Natural contents of heavy metals in some Brazilian soil classes. Bragantia 2002, 61, 151-159. [CrossRef]

50. O'Kelly, B.C.; Quille, M.E. Shear strength properties of water treatment residues. Proc. Inst. Civ. Eng. Geotech. Eng. 2010, 163, 23-35. [CrossRef]

51. Balkaya, M. Evaluation of the geotechnical properties of alum sludge, zeolite, and their mixtures for beneficial usage. Environ Prog. Sustain. Energy 2015, 34, 1028-1037. [CrossRef]

52. Trenter, N. Earthworks: A Guide, 1st ed.; Thomas Telford: London, UK, 2001.

53. Murray, E.J.; Rix, D.W.; Humphrey, R.D. Clay linings to landfill sites. Q. J. Eng. Geol. 1992, 25, 371-376. [CrossRef]

54. Pozzebon, B. Parameters of Compacted Residual Soils from the Sao Paulo's Metropolitan Region: A Comparison with Data from Other Brazilian Regions. Master's Thesis, University of Sao Paulo, Sao Paulo, Brazil, 2017.

55. Mewis, J.; Wagner, N.J. Thixotropy. Adv. Colloid Interface Sci. 2009, 147-148, 214-227. [CrossRef]

56. Mewis, J. Thixotropy-A general review. J. Nonnewton. Fluid Mech. 1979, 6, 1-20. [CrossRef]

57. Malkin, A.Y. Rheology Fundamentals; ChemTec Publishing: Scarborough, ON, Canada, 1994; ISBN 1-895198-09-7.

58. Tadros, T.F. Rheology of Dispersions; Wiley: Hoboken, NJ, USA, 2010; Volume 44, ISBN 978-3-527-32003-5.

59. Eshtiaghi, N.; Markis, F.; Yap, S.D.; Baudez, J.C.; Slatter, P. Rheological characterisation of municipal sludge: A review. Water Res. 2013, 47, 5493-5510. [CrossRef]

60. Ratkovich, N.; Horn, W.; Helmus, F.P.; Rosenberger, S.; Naessens, W.; Nopens, I.; Bentzen, T.R. Activated sludge rheology: A critical review on data collection and modelling. Water Res. 2013, 47, 463-482. [CrossRef]

61. Seyssiecq, I.; Ferrasse, J.; Roche, N. State-of-the-art: Rheological characterisation of wastewater treatment sludge. Biochem. Eng. J. 2003, 16, 41-56. [CrossRef]

62. Aguiar, T.D.; Scalize, P.S. Caracterização de lodo de tratamento de água para abastecimento através de sistema de eletroflotofiltração (SEFF). In Proceedings of the First Meeting of Water Treatment Sludge-Connections for Technology Innovation (LETA2021), Online Event, 17-19 June 2021; Available online: https:/ /www.ggga.ita.br/Anais_LETA2021_comprimido.pdf (accessed on 25 August 2021). 